\section{Tworzenie przestrzeni dla kultury żydowskiej w polskich muzeach etnograficznych. Działania kuratorskie związane z pokazywaniem pluralizmu kulturowego w kontekście utraty różnorodności etnicznej}

Erica Lehrer, Monika Murzyn-Kupisz
TEKSTY DRUGIE 2020, NR 4, S. 155-187

DOI: 10.18318/td.2020.4.10 | Erica Lehrer - ORCID: 0000-0003-0623-1654

Monika Murzyn-Kupisz - ORCID: 0000-0002-8482-970X

$\mathbf{W}$ okresie postsocjalistycznym w Polsce można zaobserwować żywiołowy rozkwit nowych inicjatyw muzealnych, obejmujący zarówno zakładanie oraz otwieranie nowych instytucji muzealnych, jak i rozwój czy rozbudowę istniejących muzeów; tendencja ta jest szczególnie widoczna od momentu przystąpienia do Unii Europejskiej w 2004 roku'. Co istotne, zjawisko to w kontekście polskim zachodzi w momencie, gdy na arenie międzynarodowej rozwijają się nowe paradygmaty muzeologiczne. Pluralistyczne tendencje w muzealnictwie, przenikające z krajów anglosaskich i zachodnioeuropejskich, akcentują konieczność uwzględniania „europejskich” wartości ponadnarodowych oraz

1 Por. K. Jagodzińska Museums and Centres of Contemporary Art in Central Europe after 1989, Routledge, New York 2019. Wiele z powstających placówek to muzea historyczne poświęcone tematyce cenzurowanej w czasach komunizmu (np. osiągnięciom II Rzeczpospolitej, Armii Krajowej w okresie II wojny światowej i powstaniu warszawskiemu).

Dłuższa, angielska wersja tego tekstu została opublikowana jako: E. Lehrer, M. Murzyn-Kupisz Making Space for lewish Culture in Polish Folk and Ethnographic Museums: Curating Social Diversity after Ethnic Cleansing, "Museum Worlds" 2019 vol. 7, s. 82-108.

Erica Lehrer - antropolożka kultury i kuratorka. Profesorka na Uniwersytecie Concordia w Montrealu. Autorka książki Jewish Poland Revisited (2013), redaktorka książek (m.in.): Curatorial Dreams (z S.Butler, 2016); /ewish Space in Contemporary Poland (z M.Mengiem, 2015). Kuratorka wystawy Pamiątka, zabawka, talizman (2013), współorganizowała wystawę Widok zza bliska. Inne obrazy Zagłady (2018-2019) - obie w Muzeum Etnograficznym w Krakowie. Kontakt: erica.lehrer@concordia.ca

\section{Monika Murzyn-Kupisz -}

dr hab., absolwentka Uniwersytetu Ekonomicznego w Krakowie oraz uniwersytetów w Brukseli, Tilburgu, Bilbao i Loughborough. Pracuje w Instytucie Geografii i Gospodarki Przestrzennej U]. Zainteresowania badawcze: interdyscyplinarne studia miejskie, badania nad dziedzictwem, zarządzanie dziedzictwem kulturowym, funkcjonowanie muzeów. Kontakt: monika.murzyn-kupisz@uj.edu.pl 
włączania mniejszości etnicznych, kulturowych i społecznych w narrację muzealną, a także potrzebę głęboko krytycznego przemyślenia współczesnej roli muzeów w duchu postkolonialnym. Jednocześnie w Polsce można zaobserwować dwa przeciwstawne, współwystępujące dyskursy polityczne na temat przeszłości. Odzwierciedlają one odmienne, niekiedy bardzo rozbieżne koncepcje dziedzictwa kulturowego, które przekładają się na podejście do praktyki kuratorskiej. Pierwszy dyskurs rozumie je jako dziedzictwo z definicji "narodowe”, wąsko ujmuje pojęcie narodu jako ograniczone do określonej grupy etnicznej i skupia się na wybranych, heroicznych odniesieniach do przeszłości, drugi zaś kładzie nacisk na pluralizm interpretacji dziedzictwa i wielokulturowość, uwzględnia także mniej chwalebne zjawiska i wydarzenia historyczne. Konflikty na polskiej scenie muzealnej dotyczyły jak dotąd głównie instytucji skupiających się na wybranym aspekcie polskiej historii - w szczególności tematyce II wojny światowej i dziedzictwie kultury żydowskiej. Choć w mniejszym może stopniu dotyczą one muzeów o bardziej ogólnym charakterze, także muzeów kultury, placówki te ostatnio mierzą się z podobnymi wyzwaniami, zarówno podejmują pewne ryzyka, jak i stawiają czoła ich konsekwencjom.

Muzealnictwo etnograficzne, którego początki powiązane są w Polsce z szerszymi projektami konsolidacji narodowo-etnicznej, będącymi jednocześnie pod wpływem rozwoju „naukowych” kategorii etnografii jako dyscypliny pod koniec XIX wieku, wydaje się ciążyć w kierunku pierwszej ze wspomnianych wyżej narracji ${ }^{2}$. Chociaż przed II wojną światową ludność etnicznie polska stanowiła co najwyżej 6o\% ogółu mieszkańców kraju, z kolei Żydzi - 10\% populacji, etnografowie w znacznej mierze oddzielali „kulturę żydowską" od etnicznie polskich, autonomicznych dokonań kulturowych, które zakorzeniali w idei słowiańskiej i chłopskiej odrębności ${ }^{3}$. Zorientowana klasowo polityka powojennego państwa socjalistycznego odświeżyła i przekształciła tradycję celebrowania dziedzictwa narodowego i ludowego, rozumianego jako „chłopskie”, wykorzystując odziedziczone z przedwojnia instytucje muzealne i ich zbiory. Wieloetniczną historię Polski dodatkowo przysłonił Holokaust i powojenne zmiany granic kraju powiązane z niekiedy

2 Por. O. Linkiewicz Scientific Ideals and Political Engagement: Polish Ethnology and the "Ethnic Question" between the Wars, "Acta Poloniae Historica” 2016 nr 114, s. 5-27.

3 Por. K. Stauter-Halstead The Peasant as Literary and Ethnographic Trope, w: The Nation in the Village: The Genesis of Peasant Identity in Austrian Poland, 1848-1914, Cornell University Press, Ithaca 2001, s. 97-114. 
gwałtownymi przesiedleniami ludności. Wydarzenia te zaburzyły i w dużej mierze zatarły ciągłość prawie tysiącletniej obecności Żydów w Polsce. W przeciwieństwie do przedwojennej wieloetniczności w okresie powojennym kraj stał się niemal zupełnie monoetniczny, co zasadniczo nie uległo już zmianie po 1989 roku $^{4}$. Choć w ostatnich dekadach podjęto wiele istotnych działań związanych z odkrywaniem i uwypuklaniem historycznej różnorodności kulturowej Polski, inicjowanych i realizowanych zarówno przez instytucje publiczne, jak i oddolnie przez miłośników i aktywistów, wiele aspektów wieloetnicznej przeszłości Polski objęła i nadal obejmuje głęboka amnezja, zarówno w sferze publicznej, jak i prywatnej5. W szczególności odnosi się to do krytycznego ujęcia złożonych, niekiedy napiętych, relacji między etnicznymi Polakami oraz ich historycznie wieloetnicznymi sąsiadami. Biorąc pod uwagę znaczenie Żydów dla przedwojennej struktury społecznej małych miast na obszarach wiejskich, znany socjolog Jan Gross zauważył zatem z konsternacją w 2016 roku, iż „ogólnie rzecz biorąc, [często] nie wiadomo, nawet jeśli spojrzy się na lokalne muzea etn o g r a f i c z n e... [wyróżnienie autorek], że [w polskich miastach i wsiach] w ogóle istniała społeczność żydowska".

Gross i inni badacze ${ }^{7}$ wydobyli na światło dzienne nierzadko trudne do akceptacji historyczne i kulturowe fakty, rozpoczynając trwającą już od dwóch dziesięcioleci publiczną debatę nad pytaniem, czy Polska jest w stanie przyjąć żydowskość jako część wyobrażonego narodowego „my”. Sposób traktowania tematów związanych z dziedzictwem kultury żydowskiej

4 Por. J. Lukowski, H. Zawadzki A Concise History of Poland, Cambridge University Press, Cambridge 2006; B. Porter-Szücs Poland in the Modern World: Beyond Martyrdom, Wiley-Blackwell, Chichester, UK 2014. W 1921 roku około 69,2\% mieszkańców Polski deklarowało narodowość polską, a W 1931 roku 68,9\% - język polski jako ojczysty (kolejnymi najczęściej wskazywanymi jako języki ojczyste były ukraiński i jidysz). Identyfikacja religijna obywateli Polski w 1931 roku wyglądała następująco: rzymski katolicyzm - 64,8\%, prawosławie - 11,8\%, grekokatolicyzm $10,4 \%$ i judaizm - 9,8\%.

5 Por. J. Nowak, S. Kapralski, D. Niedźwiedzki On the Banality of Forgetting: Tracing the Memory of Jewish Culture in Poland, Peter Lang, New York 2018.

6 O. Aderet Historian Who Shed Light on WWII Massacres Goes from Honoree to "Pole Hater", "Ha'aretz", 01.03.2016, www.haaretz.com/jewish/.premium-the-pole-who-is-breaking-the-silence-1.5410809 (20.09.2020).

7 Zob. np. B. Engelking Jest taki piękny słoneczny dzień... Losy Żydów szukających ratunku na wsi polskiej 1942-1945, Stowarzyszenie Centrum Badań nad Zagładą Żydów, Warszawa 2011. J. Tokarska-Bakir Rzeczy mgliste, Wydawnictwo Pogranicze, Sejny 2004. 
w publicznych muzeach można w tym kontekście postrzegać jako barometr zmian społecznych i politycznych. I rzeczywiście, w ostatnich dekadach widoczność odniesień do Żydów w polskim pejzażu muzealnym znacznie wzrosła, szczególnie jeśli wziąć pod uwagę istotną rolę nowych specjalistycznych muzeów ukierunkowanych na tematykę żydowską, pełniących funkcje reprezentacyjne w kraju i za granicą ${ }^{8}$. Dziś w Polsce, gdzie żyje tylko około dwudziestu tysięcy Żydów, działa co najmniej siedem placówek o charakterze muzealnym, skupionych na odniesieniach do tej grupy etnicznej (dwie kolejne są w budowie) - od skromnych, ale znaczących instytucji w Chmielniku, Płocku, Krakowie czy Lublinie ${ }^{9}$ do światowej klasy Muzeum Historii Żydów Polskich POLIN w Warszawie, dysponującego wielomilionowym budżetem. Jego otwarcie w 2014 roku zostało w polskiej i międzynarodowej prasie uznane za wydarzenie przełomowe dla polskich rozliczeń z przeszłością (Vergangenheitsbewältigung) i polsko-żydowskiego pojednania. "The Economist" ${ }^{\text {10 }}$ przewidywał, że ta nowa instytucja - z północnoamerykańską badaczką Barbarą Kirshenblatt-Gimblett na czele zespołu kuratorskiego, mająca zarówno lokalne, jak i międzynarodowe zaplecze - „zintensyfikuje debatę o tym, jak muzea powinny przedstawiać kwestię tożsamości narodowej", do czego rzeczywiście doszło.

Muzea różnią się jednak między sobą pod względem historii powstawania, przyjętych epistemologii, profilu odbiorców, ról i wartości społecznych,

8 Gdy w okresie schyłkowego socjalizmu rozluźniła się kontrola rządu nad kulturą, zrealizowano kilka niezwykłych projektów muzealnych dotyczących tematyki żydowskiej. Dwie wystawy w czasie transformacji politycznej 1989-1990: Polscy Żydzi (od grudnia 1989 do lutego 1990) w Muzeum Narodowym w Krakowie i Żydzi wrocławscy 1850-1944 (otwarta w marcu 1989 roku w Muzeum Architektury we Wrocławiu) przyciągnęły tłumy oraz zwróciły uwagę na kwestię historycznej obecności Żydów na terenach Polski. Zob. V. Kretschmann Entangled Heritage: Wrocław's German-Jewish and Polish-Jewish History Exhibitions, 1920-2010, "Kultura Popularna" $2017 \mathrm{nr}$ 1(50), s. 92-102.

Można tu wymienić np. Ośrodek Edukacyjno-Muzealny „Świętokrzyski Sztetl” w Chmielniku, Żydowskie Muzeum Galicja w Krakowie, Ośrodek „Brama Grodzka - Teatr NN” w Lublinie oraz nowy oddział Muzeum w Gliwicach zajmujący się historią Żydów na Śląsku. Odniesienia do obecności Żydów w Polsce są powszechne w nowych regionalnych muzeach historycznych, takich jak spektakularne Muzeum Śląskie w Katowicach (nowa siedziba otwarta w 2015 roku), a także skromniejsze Muzeum Pienińskie im. ). Szalaya w Szlachtowej (nowa siedziba otwarta w 2014 roku), które uwzględnia żydowskich mieszkańców i kuracjuszy na wystawie poświęconej historii i kulturze Pienin oraz uzdrowiska Szczawnica. 
a także struktur organizacyjnych i finansowych. W niedawno opublikowanym dokumencie odnotowano, że "chociaż opinia publiczna koncentruje się na mniej niż dwudziestu «najważniejszych» polskich muzeach, na cały sektor składa się niemal tysiąc instytucji, których działalność jest często ignorowana w dyskursie, ale doceniana przez zwiedzających"11. Z badania przeprowadzonego w 2011 roku wynika, że ponad 220 polskich muzeów posiada kolekcje judaików lub wystawy prezentujące treści związane ż̇ydami ${ }^{12}$. Warto zatem uwzględnić w rozważaniach także muzea ni eży d o w s ki e, w których odwiedzający mogą napotkać muzealia i odniesienia do kultury żydowskiej, choć nie należą one do wspomnianej, względnie nielicznej, grupy specjalistycznie ukierunkowanych „muzeów żydowskich". W badaniach nad nowymi placówkami muzealnymi niewiele uwagi poświęcono bowiem jak dotychczas przemianom istniejących od dawna instytucji, które nie skupiają się wyraźnie na żydowskim dziedzictwie, lecz zaczynają uwzględniać tę tematykę na swoich wystawach i robią to na większą niż dotąd skalę lub zmieniają dotychczasową narrację.

Niniejszy artykuł skupia się na dwóch największych muzeach etnograficznych w Polsce, stawiając pytanie o to, jak instytucje tego rodzaju reagują na ogólniejszą tendencję do włączania tematyki żydowskiej w opowieść o polskim dziedzictwie narodowym. Te instytucje kultury - bardziej „uniwersalne”, mające własną publiczność, infrastrukturę, zbiory, personel i tradycje - lepiej, naszym zdaniem, odzwierciedlają strukturalne i polityczne wyzwania związane z uznaniem żydowskości (w jej różnorodnych przejawach) za integralną część polskiego dziedzictwa kulturowego, co pozwala obserwować dotyczące ich zmiany w podejściu muzeologicznym, a także towarzyszącą im inercję, napięcia i obawy. Owe zmiany stosunku do uwzględniania treści związanych z kulturą i historią żydowską ukazują p r z ej ś c i e od tradycyjnego

11 . Bukowiecki Things of Warsaw and Things of the Past: Evolution and Priorities of the Museum of Warsaw, Museum of Warsaw Report\#1, ECHOES Horizon 2020 Grant Project: European Colonial Heritage Modalities in Entangled Cities. Grant Agreement No. 770248. University of Warsaw. http://projectechoes.eu/wp-content/uploads/Bukowiecki-Museum-of-Warsaw-Report-1. pdf (02.11.2019).

12 D. Folga-Januszewska 1000 Museums in Poland: A Guide, Bosz, Olszanica 2011. Dla porównania W 1979 roku odnotowano obecność obiektów sztuki żydowskiej w ponad 60 polskich muzeach (zob. I. Rejduch-Samkowa Sztuka żydowska w Polsce, ")udaica” 2011, http:// judaica-art.com. pl/, 20.09.2020). Zestawienie opracowane we współpracy z Muzeum Historii Żydów Polskich POLIN (S. Kryciński, A. Olej-Kobus, K. Kobus Zabytki kultury żydowskiej w Polsce: przewodnik, Carta Blanca, Warszawa 2011) obejmuje dziś ponad 60 muzeów i wystaw wartych uwagi turystów zainteresowanych kulturą żydowską. 
status quo do szerokiego zakresu nowych sposobów pojmowania tożsamości narodowych ${ }^{13}$.

\section{Żydzi w polskich muzeach etnograficznych}

W Europie Środkowej i Wschodniej muzea etnograficzne były tradycyjnie postrzegane jako strażnice kultury narodowej i narzędzia wytwarzania tożsamości narodowej. Jako instytucje związane są z kształtowaniem się narodów w XIX wieku, wypracowanym przez podkreślanie odrębności i różnic między grupami kulturowymi (etnos) ${ }^{14}$. W wielokulturowych miastach, takich jak Lwów, Wilno, Kraków czy Warszawa pod rządami imperiów rosyjskiego oraz austro-węgierskiego, muzea takie były świadomie wiązane z procesami budowania i definiowania narodu polskiego. Powstające w okresie obcych rządów, kiedy Polska nie istniała jako suwerenne państwo, były zatem inicjatywami oddolnymi, obywatelskimi, a nie sponsorowanymi przez władze publiczne. Znajdowały się pod tym większą presją, by „nieść sztandar" wyobrażonej wspólnoty narodowej i wyrażać polskie aspiracje państwowe.

Polscy Żydzi - usiłując w ramach dominującego wówczas paradygmatu stać się uznanym, „normalnym” narodem - wypracowali własną tradycję badań etnograficznych, czy to tworząc wizję żydowskiej odrębności narodowej, czy domagając się własnego miejsca w ramach pluralistycznej zbiorowości polskiej ${ }^{15}$. Za sprawą szerszego rozwoju muzealnictwa etnograficznego niekiedy byli wspierani przez swoich „etnicznie” polskich kolegów albo przynajmniej pozostawali z nimi w dialogu. Ich tradycje

13 Struktura organizacyjna polskich muzeów również zmieniła się znacząco od 1989 roku, a zwłaszcza w ciągu ostatnich 15 lat. Po wprowadzeniu nowego podziału administracyjnego kraju i nowych szczebli samorządu terytorialnego (gminnego, powiatowego i wojewódzkiego) W 1999 roku niewiele muzeów jest nadal finansowanych bezpośrednio przez Ministerstwo Kultury i Dziedzictwa Narodowego (Por. „Rejestry muzeów”, Ministerstwo Kultury i Dziedzictwa Narodowego, http://bip.mkidn.gov.pl/pages/rejestry-ewidencje-archiwa-wykazy/rejestry-muzeow.php, 8.02.2019). Większość placówek - w tym dwie, o których piszemy - jest obecnie prowadzona i finansowana przez samorządy wojewódzkie, powiatowe lub gminne.

Por. O. Linkiewicz Scientific Ideals. Podejście to wypływało z XIX-wiecznego, esencjonalnego pojmowania tożsamości narodowo-etnicznych w duchu herderowskim.

15 Zob. Writing Jewish Culture: Paradoxes in Ethnography, ed. A. Kilcher, G. Safran, Indiana University Press, Indiana 2016; Going to the People: Jews and the Ethnographic Impulse, ed. J. Veidlinger, Indiana University Press, Bloomington 2016. 
i aspiracje zostały jednak unicestwione podczas II wojny światowej wraz z większością Żydów europejskich. Rozproszyły się ich zbiory: niektóre zagrabili lub zniszczyli naziści, niektóre znacjonalizowały powojenne władze, inne zaś zostały przejęte przez nowe państwo Izrael lub Stany Zjednoczone jako żydowskie dziedzictwo. Dzisiejsze fragmentaryczne kolekcje etnograficzne proweniencji żydowskiej ze zbiorów polskich muzeów etnograficznych jedynie w okrojony sposób oddają więc przedwojenne koncepcje i wysiłki na rzecz tworzenia wyobrażeń o kulturze żydowskiej i jej miejscu w kulturze narodowej.

W dobie PRL, zgodnie z ogólną polityką podkreślania jednolitości etnicznej i monokulturowości, muzea znajdowały się pod presją, aby podtrzymywać i podkreślać etno-narodowe podejście i wyobrażenie o polskiej tożsamości narodowej. Te dyskursy i praktyki miały zarazem oswajać i legitymizować socjalizm, zapobiegać jego odrzuceniu jako obcego i narzuconego przez Związek Radziecki. W okresie powojennym ze względów strategicznych odniesienia do mniejszości narodowych pojawiały się od czasu do czasu w narracji muzealnej, ale dotyczące ich treści ujmowano w taki sposób, aby były podporządkowane tej polityce ${ }^{16}$.

Instytucje muzealne nadal w dużej mierze tkwią w romantycznym paradygmacie etnografii muzealnej. Trudności w uwzględnianiu w narracjach muzealnych „kwestii żydowskiej”, niewpisującej się w „prosty” podział Europy na państwa narodowe, odzwierciedlają znaczące wyzwania wynikające z utrzymującego się monoetnicznego pojmowania wspólnot narodowych. Podejścia obecne we współczesnych polskich muzeach etnograficznych są więc zasadniczo powiązane z ideologią, w ramach której, w szczególności w latach 1945-1989, postrzegano „mniejszości narodowe”, w tym Żydów, jako byty w dużej mierze zewnętrzne wobec spraw „własnej” wspólnoty lub jako problematyczne „przeszkody” do pokonania

16 W kwietniu 1960 roku „wystawa poświęcona sztuce ludowej Białorusinów, Litwinów, Rosjan, Słowaków, Ukraińców i Żydów mieszkających w Polsce", zawierająca około 500 przedmiotów "sztuki ludowej", została zorganizowana w Muzeum Etnograficznym w Krakowie przez Marię Woleńską z Muzeum Narodowego w Krakowie, z inicjatywy Ministerstwa Kultury i Sztuki w ramach obchodów tysiąclecia państwa polskiego. Niezależnie od tego, czy zamierzano w ten sposób rywalizować z Kościołem katolickim, obchodzącym w tym samym roku tysiąclecie polskiego chrześcijaństwa, czy też skorzystać z możliwości stworzonych w czasie postalinowskiej odwilży, kilka lat później, w latach 1967-1968, Żydzi ponownie stali się ofiarą nagonki, a zarazem wykluczenia z narracji muzealnej. Zob. M. Woleńska Wystawa sztuki ludowej zamieszkałych w Polsce Białorusinów, Litwinów, Rosjan, Słowaków, Ukraińców, Żydów, Muzeum Etnograficzne im. Seweryna Udzieli, Kraków 1960. 
w poszukiwaniu idealnego (rozumianego etnicznie) narodu. Dlatego też aktualne próby wprowadzania tematyki żydowskiej do wystaw muzealnych muszą dziś iść w parze z procesami ogólniejszego przedefiniowania pojęć narodu, kultury i etnografii. Ze względu na to, że w krajach zachodnich muzea etnograficzne były ściśle związane z XIX-wiecznymi próbami zdefiniowania kultury i powiązania jej z określonymi społecznościami jako uzasadnienia kolonialnej ekspansji, ich autorytet i status prawowitych strażników kultury został w ostatnich latach zasadniczo zakwestionowany, co zmusiło je do zmiany paradygmatu jej prezentowania ${ }^{17}$.

O ile jednak w kulturze zachodniej, biorąc pod uwagę współczesne zróżnicowanie interpretacji dziedzictwa, muzea etnograficzne zdają się tracić zasadniczą funkcję, którą swego czasu sprawowały jako dostarczyciele „jedynie prawdziwej”, dominującej, opartej na naukowych podstawach tożsamości, to w Polsce wciąż mogą one odgrywać znaczącą rolę społeczną. Istotność muzeów etnograficznych w tym kontekście wynika z kilku czynników: 1. placówki te poświęcają uwagę nie tyle kulturze elitarnej, ile życiu tzw. „zwykłych ludzi”, powszechnie postrzegane są zatem jako instytucje reprezentujące demokratyczne podejście do kultury; 2. pełnionej przez nie funkcji atrakcyjnych miejsc wycieczek szkolnych oraz nieformalnej, pozaszkolnej edukacji dzieci i rodzin; oraz 3. odrodzenia zainteresowania, którego doświadczają ze względu na rosnącą popularność estetyki „folkowej”, , etnodizajnu” i „zrób to sam" (mniej popularnej w latach 9o. ubiegłego wieku ze względu na skojarzenia z ideologią komunistyczną, pomimo silnej tradycji odniesień do ludowości w polskiej sztuce i wzornictwie, utrzymującej się od XIX wieku) ${ }^{18}$.

17 Zob. F. Boursiquot Ethnographic Museums: From Colonial Exposition to Intercultural Dialogue, w: The Postcolonial Museum: The Arts of Memory and the Pressures of History, ed. I. Chambers i in., Ashgate, Burlington 2014, S. 76-83; B. Durrans The Future ofEthnographic Exhibitions , "Zeitschrift für Ethnologie" 1993 nr 118 (1), s. 125-139, www.jstor.org/stable/25842302 (20.09.2020); C. Harris, M. O'Hanlon The Future of the Ethnographic Museum, "Anthropology Today" 2013 nr 29 (1), s. 1-32, www.jstor.org/stable/23486436 (20.09.2020); Matters of Belonging: Ethnographic Museums in a Changing Europe, ed. W. Modest, N. Thomas, D. Prlić, C. Augustat, Sidestone Press, Leiden 2019; Museums in Postcolonial Europe, ed. D. Thomas, Routledge, Abingdon, UK 2009. Polish Countryside, w: Art in Contemporary Cultural Systems, ed. W. Kuligowski, A. Pomieciński, Wydawnictwo Nauka i Innowacje, Poznań 2014, s. 49-62; E. Klekot The Seventh Life of Polish Folk Art and Craft, "Etnološka Tribina” 2010 nr 33 (40), s. 71-85, https://hrcak.srce.hr/63180 (20.09.2020). 
Z tych względów nasze badania dotyczą sposobów pokazywania („odzwierciedlenia") Żydów w nieżydowskich muzeach w Polsce i koncentrują się na dwóch największych, istotnej wagi muzeach etnograficznych: Państwowym Muzeum Etnograficznym w Warszawie i Muzeum Etnograficznym im. Seweryna Udzieli w Krakowie. Nowe, „krytyczne” oraz postkolonialne teorie były głównymi narzędziami służącymi do analizy muzeów etnograficznych na Zachodzie, a także najważniejszymi katalizatorami zachodzących w nich zmian. Sposoby - czy nawet sama możliwość - praktycznego zastosowania takiego podejścia do muzealnictwa etnograficznego (lub innego) w Polsce nie były jednak szeroko dyskutowane ${ }^{19}$, chociaż polskie muzea etnograficzne zasadniczo opierają się obecnie na podobnych epistemologicznych i wystawienniczych podstawach tak jak ich zachodnie odpowiedniki ${ }^{20}$. Debaty te zaczęły pojawiać się w Polsce relatywnie niedawno dzięki podróżom i spotkaniom polskich oraz zagranicznych uczonych, artystów, kuratorów i działaczy społecznych - w czym same brałyśmy udział.

W dalszej części tekstu stawiamy zatem pytanie, jakie wyzwania napotykają w Polsce te nowe, ,importowane” koncepcje, a także jakiego rodzaju twórcze "napięcia” mogą powodować w powiązaniu z istniejącymi lokalnymi paradygmatami i źródłami innowacji w muzeach. Interesuje nas zrozumienie czynników inspirujących i ograniczających stopniowe zmiany w polskich muzeach etnograficznych, a także wzajemnych oddziaływań między ich egzo- i endogenicznymi „źródłami”, jakie ujawniają się, gdy muzea te podejmują próby zmierzenia się z ciężarem i złożonością polskiej historii.

19 Por. Ł. Bukowiecki Things of Warsaw; Ł. Bukowiecki, J. Wawrzyniak Dealing with Difficult Pasts at the Museum of Warsaw: Implications of Curatorial Memory Practices. Museum of Warsaw Report \#2, ECHOES Horizon 2020 grant project: European Colonial Heritage Modalities in Entangled Cities, grant agreement No. 770248, http://projectechoes.eu/wp-content/uploads/ Bukowiecki-Wawrzyniak-Museum-Of-Warsaw-Report-2_compressed.pdf (24.11.2019); K. Murawska-Muthesius Love of Beauty in the Tsarist Colonial Capital: The Museum of Fine Arts in Warsaw (1862-1916), "Centropa" 2012 nr 12 (2), s. 179-193; K. Murawska-Muthesius, P. Piotrowski Introduction, w: From Museum Critique to the Critical Museum, Routledge, London 2017, s. 1-14, P. Piotrowski Muzeum krytyczne, Dom Wydawniczy REBIS, Poznań 2011. polskich, z uwzględnieniem koncepcji ogólnoeuropejskiego "umysłu kolonialnego", zob. M.Grzechnik The Missing Second World: On Poland and Postcolonial Studies, "Interventions” 2019 vol. 21 (7), s. 998-1014. 


\section{Wyraźne odseparowanie ${ }^{21}$ : \\ Państwowe Muzeum Etnograficzne w Warszawie}

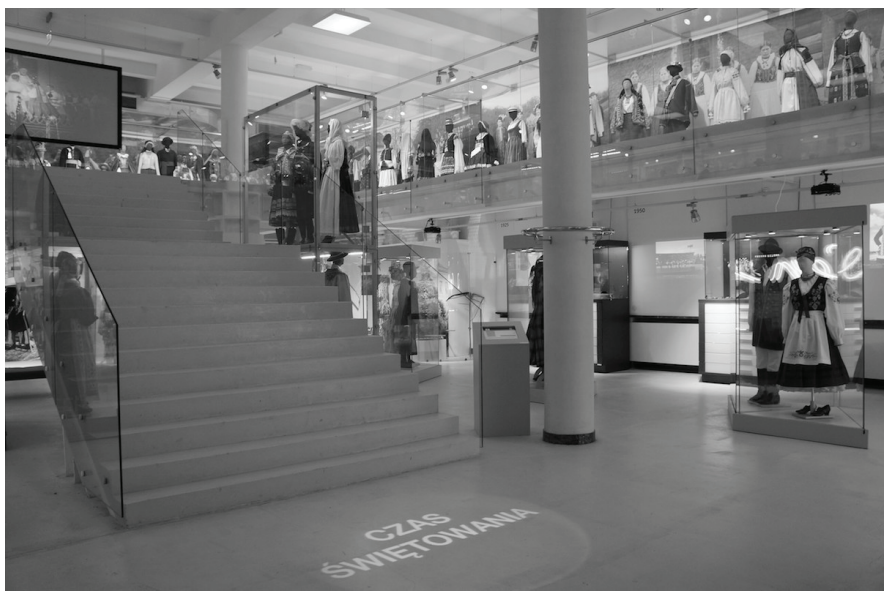

Ilustracja 1. Stała wystawa główna „Czas świętowania”. Zdjęcie dzięki uprzejmości Moniki Murzyn-Kupisz.

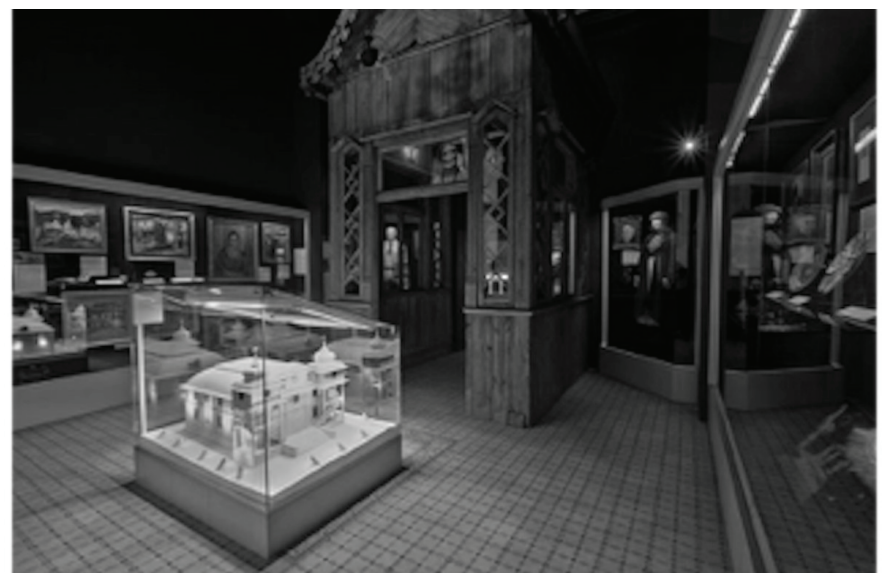

Ilustracja 2. „Żydowski aneks”. Zdjęcie dzięki uprzejmości Eriki Lehrer.

21 W angielskiej wersji podtytułu użyto sformułowania "Two Solitudes" (Dwie samotności), które pierwotnie odnosiło się do braku komunikacji i samej woli komunikowania się między angloi francuskojęzycznymi mieszkańcami Kanady (i nadal funkcjonuje w tym kontekście). Termin ten został spopularyzowany przez powieść Hugh MacLennana z 1945 roku Dwie samotności. Używamy go tutaj jako sugestywnej metafory, a nie ścisłej paraleli. 
Państwowe Muzeum Etnograficzne w Warszawie, założone w 1888 roku, jest najstarszą tego typu instytucją w Polsce. Jego oryginalna kolekcja została w większej części zniszczona podczas II wojny światowej. Starano się ją odtworzyć i rozwinąć w okresie powojennym. Po 1945 roku muzeum początkowo mieściło się w pałacu na Młocinach. Od 1973 roku zbiory znajdują się

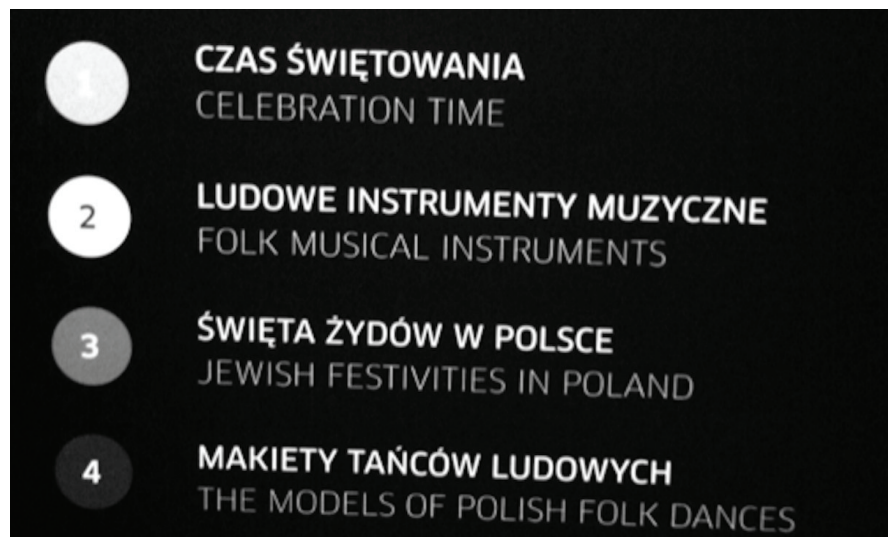

Ilustracja 3. Opisy poszczególnych części stałej wystawy głównej. Zdjęcie dzięki uprzejmości Eriki Lehrer.

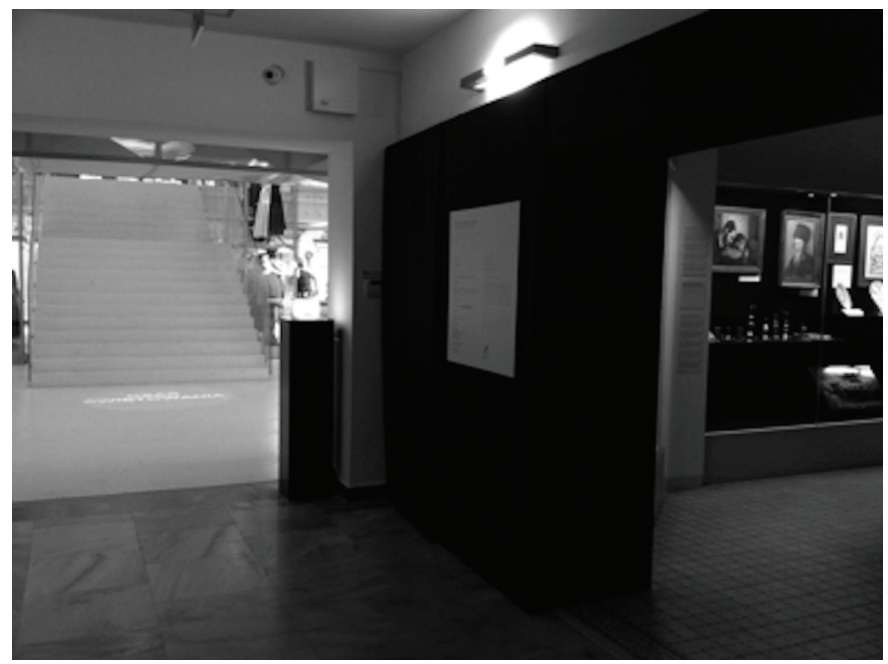

Ilustracja 4. Po lewej: wejście na wystawę Czas świętowania. Po prawej: wejście do „aneksu żydowskiego” (przed zainstalowaniem oryginalnych elementów kuczki). Zdjęcie dzięki uprzejmości Eriki Lehrer. 
w zrekonstruowanym dawnym budynku Towarzystwa Kredytowego Ziemskiego, w sercu Warszawy, przy skrzyżowaniu ulic Kredytowej i Mazowieckiej, naprzeciwko budynku Zachęty - Narodowej Galerii Sztuki. Projekty najważniejszych galerii oraz ich konfiguracje tematyczne, opracowane przez etnografa i historyka sztuki Ksawerego Piwockiego w 1961 roku, były jak na owe czasy bardzo innowacyjne, ponieważ stworzono je w celu podkreślenia powiązań między procesami kulturowymi, historycznymi i politycznymi - uwzględniając „bazową sytuację etniczną i perypetie historyczne” kraju ${ }^{22}$. Jednak ze względu na brak remontów, powiększanie kolekcji i problemy finansowe w latach 90. muzeum było w dużej mierze niewidoczne w ofercie kulturalnej miasta. Dopiero na początku XXI wieku zaczęto wprowadzać większe zmiany we wnętrzach muzealnych, a zwłaszcza od 2008 roku, kiedy mianowano nowego dyrektora ${ }^{23}$. Obejmowały one remont budynku, nowe wystawy oraz otwarcie Muzeum dla Dzieci (2013) - niewielkiej wydzielonej części muzeum, która koncentruje się na organizowaniu warsztatów dla młodszych zwiedzających. Kolekcja muzealna obejmuje ponad 80000 obiektów, w tym 2300 depozytów; w muzeum pracują 72 osoby, odwiedza je ponad 76 tys. osób rocznie (2015).

W 2013 roku muzeum zakończyło poważne prace remontowo-budowlane budynku obejmujące ponad 6o\% jego powierzchni użytkowej. Jednocześnie otwarto nową wystawę stałą w galerii głównej, zatytułowaną Czas świętowania w kulturach ludowych Polski $i$ Europy, o powierzchni ponad 850 metrów kwadratowych. Według wyjaśnień dyrektora Adama Czyżewskiego nowa, kompleksowa wizja wystawy „realizuje jeden z podstawowych postulatów metodologicznych współczesnej antropologii kulturowej i muzeologii”, budując narrację tak, by osiągnąć

stan równowagi pomiędzy tekstualnym a performatywnym rozumieniem [...] kultury. [Wystawa] wzbogaca wiedzę odbiorcy, a jednocześnie uruchamia pokłady jego wrażliwości, emocji - staje się obiektem przeżycia estetycznego. Posługuje się komentarzem słownym, ale skuteczność przekazu zawdzięcza przede wszystkim obrazom, obiektom, scenografii i architekturze.

K. Piwocki Warszawskie Muzeum Etnograficzne, "Etnografia Nowa/The New Etnography" 2013 nr 5, s. 50. Zob. też A. Czyżewski Transformacja Państwowego Muzeum Etnograficznego w Warszawie 2008-2012, „Etnografia Nowa/The New Ethnography” 2013 nr 5, s. 10-33.

23 Od 1999 roku muzeum jest nadzorowane przez samorząd terytorialny [Samorząd Województwa Mazowieckiego - przyp. red.]. 
Wystawa nie jest wykładem, który opisywałby w formie liniowej skończoną, zamkniętą, a de facto tylko jedną z wielu możliwych wizji rzeczywistości. Jest więc opowieścią o kulturach ludowych, a nie o kulturze ludowej. Ukazuje je w mnogości relacji, narracji, nieustannie zmieniające się w czasie ${ }^{24}$.

W rezultacie powstała atrakcyjna, błyskotliwa wystawa zwyczajów i artefaktów polskiej wsi, zajmująca dwa piętra muzeum (il.1). Przestrzeń ta przypomina raczej galerię handlową niż gabinet osobliwości; wystawione obiekty są uzupełnione materiałami filmowymi, które łączą dawne praktyki kulturowe z teraźniejszością. Nowa wystawa korzysta z „postmodernistycznych” inspiracji teoretycznych, uwspółcześniając prezentowaną historię np. dzięki uwzględnieniu sekcji dotyczącej państwowej instytucji zajmującej się sztuką ludowej - Cepelii - którą zaznacza neon z jednego ze sklepów tej sieci, wszechobecnych w komunistycznej Polsce od lat 50.

Strona internetowa Państwowego Muzeum Etnograficznego opisała nową ekspozycję w następujący sposób: „to największa i najważniejsza wystawa w 125-letniej historii [tego muzeum - przyp. red.]. [Wystawa] jest barwną wielogłosową opowieścią ukazującą rytuały, obyczaje i akcesoria świąteczne różnych tradycji i obrząadków religijnych w Polsce"25. W głównej galerii, choć w osobnej sekcji, znalazły się materiały dotyczące Kościoła prawosławnego, Kościoła greckokatolickiego, Ormian i innych mniejszości. Pokazanie ich odrębności ograniczone jest jednak do przedstawienia wierzeń i zwyczajów religijnych.

Żydowskie treści kulturowe zostały zaaranżowane w inny sposób. Są bardziej widoczne, ale całkowicie oddzielone od głównej przestrzeni ekspozycyjnej (il. 2). Tuż przed wejściem na wystawę Czas świętowania, po prawej stronie, znajduje się drugie wejście prowadzące do galerii zatytułowanej Święta Żydów w Polsce (il. 3), którą Czyżewski czule nazywa „aneksem”26. W przeciwień-

24 A. Czyżewski Czas świętowania - założenia metodologiczne wystawy, w: Czas świętowania w kulturach Polski i Europy, red. A. Czyżewski, Państwowe Muzeum Etnograficzne w Warszawie, Warszawa 2013, s. 11.

25 [Cytowany fragment znajdował się na stronie internetowej PME, jak również w materiałach prasowych dotyczących wystawy, w których można odnaleźć go nadal: por. np. https://kulturalna.um.warszawa.pl/wydarzenia,1,144547.html?locale=pl_PLEbb=1; współczesny, nieco zmieniony opis wystawy Czas świętowania: https://ethnomuseum.pl/wystawy/czas-swietowania/ (w obu wypadkach dostęp 20.09.2020). Przyp. red.]

26 K. Bielawski, A. Stankowski Czyżewski: Ludzie nie kojarzq kultury żydowskiej z etnografiq „ „Wirtualny Sztetl" 29.10.2014, https://sztetl.org.pl/pl/tradycja-i-kultura-zydowska/wywiady/ 
stwie do białego, przestronnego, jasno oświetlonego holu głównego (il. 4) „aneks żydowski” - który zajmuje jedynie 36 metrów kwadratowych, czyli 4\% powierzchni Czasu świętowania - przypomina grotę. Jego ściany pomalowano matową, czarną farbą. Szklane gabloty otaczające galerię zawierają wiele żydowskich obiektów rytualnych, zarówno historycznych, jak i współczesnych, podarowanych przez dzisiejszą warszawską społeczność żydowską lub od niej pożyczonych, w tym chanukowe menory i drejdle, talerze sederowe, tefiliny i modlitewniki. Znajduje się tam też seria obrazów wybitnych polskich artystów żydowskich XIX i XX wieku (m.in. Artura Markowicza, Henryka Lewensztadta, Maksa Hanemana, Henryka Gotliba oraz Artura Szyka), a także kilka współczesnych dzieł, takich jak wycinanki artystki Moniki Krajewskiej. W galerii wyświetlane jest również w sposób ciągły wideo z przedwojennymi czarno-białymi filmami jidysz - w tym ze słynnym Dybukiem - ilustrujące żydowskie rytuały świąteczne.

Choć „aneks” miał zdaniem dyrektora muzeum towarzyszyć wystawie głównej od początku opracowania jej koncepcji w 2010 roku, już po otwarciu wystawy został znacząco zmodyfikowany. Do ekspozycji dołączono drewnianą makietę głównej, nieistniejącej już, synagogi z miasta Gąbin (jidysz: Gombin) i film dokumentalny na jej temat. Począwszy od 2015 roku do „aneksu" wchodzi się przez wejście do zrekonstruowanej kuczki z Szydłowca ${ }^{27}$.

Wspomnianą wystawę Państwowego Muzeum Etnograficznego można uznać za krok milowy w zakresie pokazywania złożoności polskiej kultury ludowej. Prosty gest włączenia obrazu kultury żydowskiej w wystawę flagowego muzeum etnograficznego w Polsce wyraźnie podkreśla, że stanowi ona część polskiego dziedzictwa narodowego. Współczesne obiekty w gablotach, drewniany model synagogi i rekonstrukcja kuczki przekonują też, że współcześnie rozumiana etnografia obejmuje nie tylko odniesienia do przeszłości czy abstrakcyjnej, wyidealizowanej kultury; w jej ramach zaznacza

czyzewski-ludzie-nie-kojarza-kultury-zydowskiej-z-etnografia (20.09.2020). [Czyżewski używa w cytowanym wywiadzie sformułowania "aneks judaistyczny”. Autorki zapożyczają od niego określenie „aneks", piszą o nim jednak jako o "aneksie żydowskim” (Jewish annex), co oddajemy w polskiej wersji. Przyp. red.].

To do niedawna jedyny tego typu obiekt w kolekcjach polskich muzeów, wypożyczony z pobliskiego Muzeum Historii Żydów Polskich POLIN, gdyż według Czyżewskiego nie mieścił się na wystawie stałej POLIN. Por. Ocalona kuczka z Szydłowca została przywrócona publiczności. Muzeum Historii Żydów Polskich POLIN, www.polin.pl/pl/aktualnosci/2015/03/06/ocalonakuczka-z-szydlowca-zostala-przywrocona-publicznosci (31.10.2019). 
się również nowsze podejście o bardziej indywidualnym, uwzględniającym szeroki kontekst charakterze.

Pytanie, czy w porównaniu z innymi mniejszościami narodowymi i etnicznymi w Polsce Żydzi powinni być postrzegani jako „podobnie różni” (similarly different) czy „inaczej różni” (differently different), jest jednak przedmiotem ciągłej debaty naukowej ${ }^{28}$. Wydzielając kulturę Żydów z głównej wystawy Czas świętowania, muzeum przyjmuje to drugie stanowisko. Według Adama Czyżewskiego wystawa żydowska jest prezentowana osobno, ponieważ odzwierciedla to faktyczne historyczne oddzielenie od siebie tych kultur. Czyżewski zwraca także uwagę na istotną asymetrię: Żydzi, jako mniejszość „niższa rangą” (subaltern), byli zaznajomieni z polską kulturą i wystawieni na jej oddziaływanie znacznie bardziej niż katoliccy Polacy z kulturą żydowską, a zwłaszcza religią judaistyczną, która pozostawała im nieznana. Przyjmując tę perspektywę, muzeum automatycznie pozycjonuje zwiedzających jako typowych Polaków katolików. Wreszcie, Czyżewski sugeruje, że ten radykalny podział odpowiada zarówno polskiej - katolickiej, jak i (być może tym bardziej) żydowskiej wrażliwości dotyczącej wzajemnych różnic i kulturowej dystynkcji. Połączenie narracji mogłoby się spotkać z niezadowoleniem obu grup.

Jednak wady nowej konfiguracji są wyraźne: umieszczenie żydowskości w oddzielnej przestrzeni nadaje jej charakter wyraźnej „inności”, radykalnie różnej od tego, co można uznać za "prawdziwą," normatywną polskość. I chociaż wybór czarnej farby może być zrozumiałym znakiem żałoby po tragicznie utraconej społeczności żydowskiej, to w kontraście z bielą wystawy głównej przywołuje od dawna obecne w polskiej kulturze ludowej (a nawet szerzej, w europejskiej kulturze chrześcijańskiej) skojarzenia żydowskości z „ciemnością" i mrocznymi siłami. Z tej perspektywy wystawa może wywoływać wrażenie przestrzeni nawiedzonej przez duchy. Radykalny podział przywołuje także przestarzałą już w antropologii koncepcję jednorodnych i wyraźnie oddzielonych od siebie kultur. Nie spełnia założeń współczesnej historiografii i teorii kultury, które mogłyby pomóc wyjaśnić wzajemne przenikanie się i wpływy kulturowe pomiędzy polskimi katolikami i polskimi Żydami.

28 Dziękujemy Sarze Zarrow za tę uwagę. Zarrow przyjmuje pierwsze stanowisko, a Itzik Gottesman reprezentuje drugie. Por. Photographing the Jewish Nation: Pictures from S. An-sky's Ethnographic Expeditions, ed. E.M. Avrutin, V.A. Dymshits, A. Ivanov, H. Murav, University Press of New England, Hanover 2009; I.N. Gottesman Defining the Yiddish Nation: The Yiddish Folklorists of Poland, Wayne State University Press, Detroit 2003; S.E. Zarrow Object Lessons: Art Collection and Display as Historical Practice in Inter-War Lwów, "Polin: Studies in Polish Jewry" 2017 nr 29, s. 157-175, https://muse.jhu.edu/article/695129 (20.09.2020). 
Dość statyczny, podniosły, tradycyjny sposób ukazania dziedzictwa żydowskiego kontrastuje nie tylko z jasną, pełną życia przestrzenią Czasu świętowania, ale także z wieloma innymi nowszymi wystawami w Państwowym Muzeum Etnograficznym. Przykładem może być czasowa ekspozycja Granice (2008-2009), złożona z prowokujących zdjęć ludzi o różnych kolorach skóry, ubranych w polskie stroje ludowe, autorstwa dwóch Polaków mieszkających w Nowym Jorku²9. W wywiadzie z 2014 roku Czyżewski odniósł się do odważniejszych pomysłów wystawienniczych związanych z aneksem, które brał pod uwagę, w szczególności dołączenia do ekspozycji filmu dokumentalnego z 1979 roku przedstawiającego wieszanie, bicie, palenie i topienie kukły Judasza w Pruchniku, w Polsce południowej. Choć w ostatnich latach z powodu protestów zaprzestano na pewien czas tego rytuału, ostatnio nastąpiło jego kolejne odrodzenie ${ }^{30}$. Czyżewski wyobrażał sobie umieszczenie tego filmu jako swoistego „przejścia” łączącego główną "polską" sekcję z „aneksem żydowskim" ${ }^{\text {31. }}$ Możliwości rzeczywistego wpływu wizjonerskich dyrektorów muzeów na narrację muzealną są jednak nadal ograniczone, szczególnie w odniesieniu do kontrowersyjnych tematów.

Pod uwagę należy wziąć także szersze zmiany w krajobrazie muzealnym Warszawy. Otwarcie Muzeum Historii Żydów Polskich POLIN w 2014 roku mogło zarówno przyspieszyć, jak i utrudnić działania Czyżewskiego w sprawie utworzenia „aneksu żydowskiego" w Państwowym Muzeum Etnograficznym. Z perspektywy niektórych pracowników placówki i zwykłych obserwatorów pojawienie się w pobliżu, w tym samym mieście, instytucji specjalizującej się w historii i kulturze żydowskiej niejako „zwolniło” Państwowe Muzeum Etnograficzne z obowiązku zajmowania się tematyką, która w oczywisty sposób zdaje się należeć do „kogoś innego”. Jak zauważa Czyżewski - „ludzie nie kojarzą kultury żydowskiej z etnografią", dyscypliną silnie związaną z etnicznie pojmowaną kulturą narodową ${ }^{32}$.

Katalog stworzony na potrzeby objazdowej wersji wystawy zawiera wspomniane zdjęcia oraz krótki esej Elżbiety Czyżewskiej. Por. E. Czyżewska Introduction, w: Border Exhibition, UlsterMuseum, Belfast, 6May-12 June 2010, ed. E. Czyżewska, Adam Mickiewicz Institute, Warsaw 2010, s. 2-3.

Por. A. Kazimierczuk „Sąd nad Judaszem” wrócił do Pruchnika: Spalono kukłęŻyda”, „Rzeczpospolita", 21.04. 2019, www.rp.pl/Spoleczenstwo/190429961-Sad-nad-Judaszem-wrocil-do-PruchnikaSpalono- kukle-Zyda.html (20.09.2020); J. Tokarska-Bakir "The Hanging of Judas"; or, Contemporary Jewish Topics, "Polin: Studies in Polish Jewry" 2011 hr 24, s. 381-400. Tamże. 
Dwa przedsięwzięcia Państwowego Muzeum Etnograficznego z 2015 roku - wystawa wycinanek Moniki Krajewskiej, przedstawicielki warszawskiej społeczności żydowskiej, a także konferencja poświęcona folklorowi żydowskiemu - dodatkowo sygnalizują zaangażowanie muzeum w tę tematykę. Sugerują również jednak ograniczenia (być może - samoograniczenia) co do tego, jakie sposoby uwzględniania i ujmowania żydowskości są postrzegane jako odpowiednie, akceptowalne przez odbiorców, władze publiczne i pracowników muzealnych ${ }^{33}$. „Aneks żydowski”, szczególny, „wychodzący przed szereg" pomysł kuratorski Czyżewskiego, stanowi zatem znaczącą próbę włączenia Żydów w obszar szeroko pojętej polskiej kultury (ludowej), jako jej integralnej, choć osobnej części - a jednocześnie ukazuje ograniczenia tego podejścia.

\section{"Ambiwalentne uzewnętrznianie" (Ambivalent Externalizing): Muzeum Etnograficzne im. Seweryna Udzieli w Krakowie}

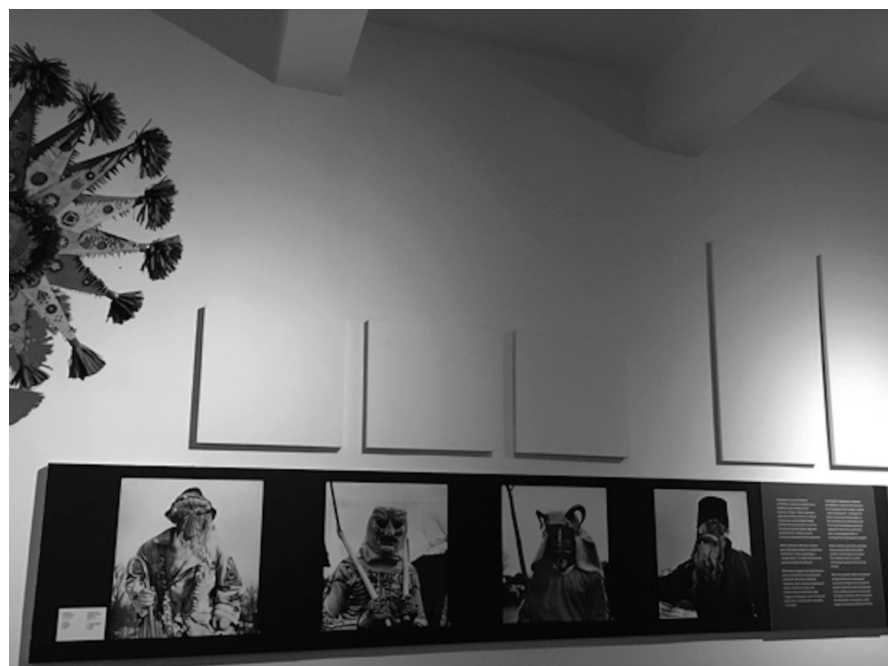

Ilustracja 5. Sala tradycji zimowych z widocznym miejscem, z którego usunięto maski żydowskie, wrzesień 2019 roku. Zdjęcie dzięki uprzejmości Eriki Lehrer.

33 Wystawa Krajewskiej nosiła tytuł Szukam raju. Materiały z konferencji Etnografia i folklorystyka żydowska w Polsce do roku 1945 zostały opublikowane w "Etnografii Nowej” (2015 nr 7 i 2016 nr 8). 


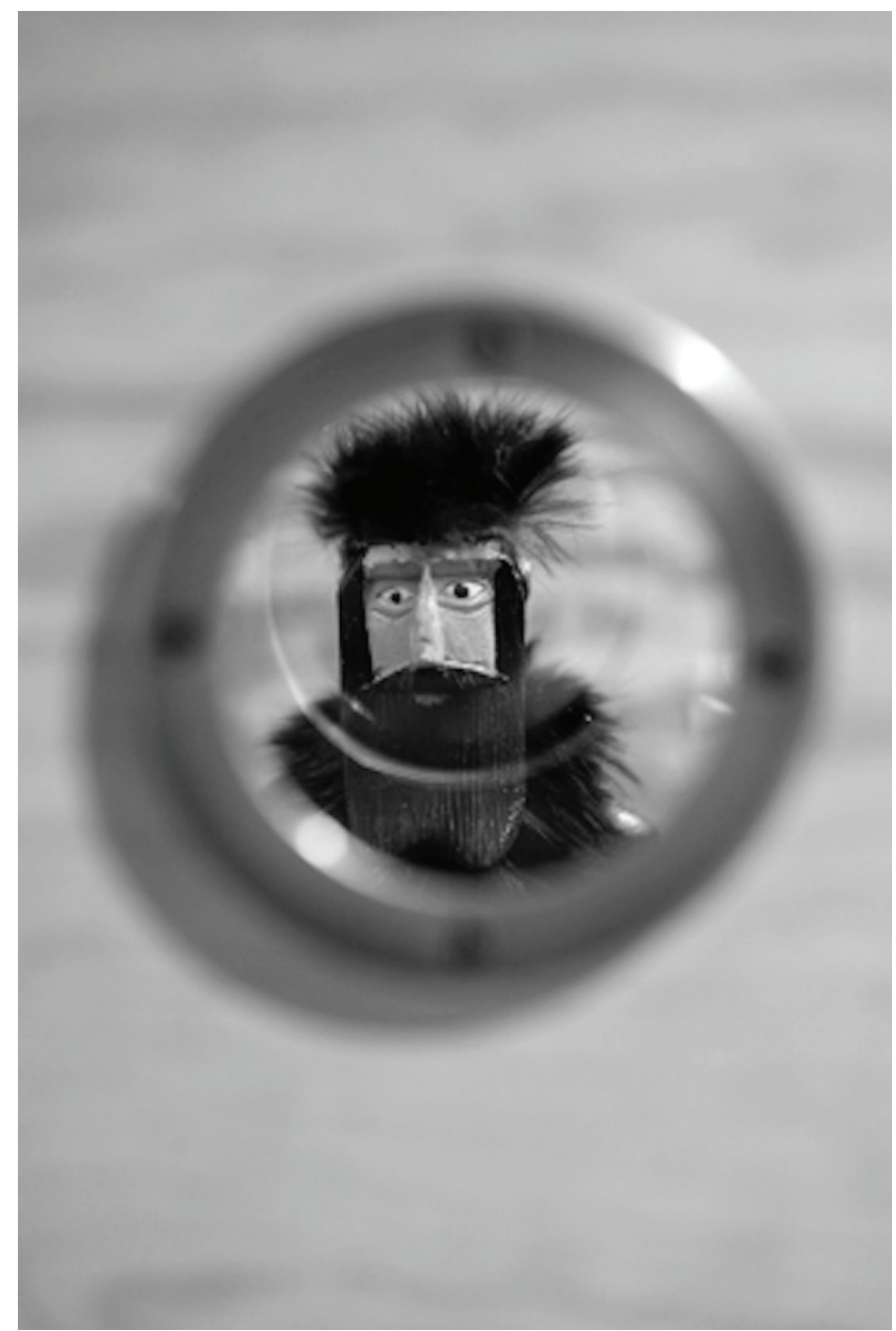

Ilustracja 6. Sala tradycji wiosennych z żydowską figurką możliwą do obejrzenia przez lupę. Zdjęcie dzięki uprzejmości Eriki Lehrer i Jasona Francisco.

Krakowskie Muzeum Etnograficzne im. Seweryna Udzieli zostało założone w 1911 roku jako prywatne muzeum prowadzone przez Towarzystwo Muzeum Etnograficznego. Przekształcone w państwową instytucję w 1945 roku, od 1948 roku mieści się w dawnym ratuszu na Kazimierzu, w sercu historycznej, 
żydowskiej dzielnicy Krakowa. W przeciwieństwie do omawianego wyżej Państwowego Muzeum Etnograficznego krakowskie Muzeum Etnograficzne posiada znaczące zbiory (ponad 80 tysięcy obiektów) odziedziczone z okresu przedwojennego; jest to największa, najstarsza i najlepiej zachowana autentyczna kolekcja tego typu w Polsce. Z wyjątkiem wnętrz chat na parterze (pochodzących z 1951 roku), jednej całkowicie odnowionej wystawy wiosennych obyczajów (2011) oraz nowej wystawy sztuki ludowej na drugim piętrze (Nieobjęta Ziemia, 2015), podstawowa koncepcja wystawiennicza dzisiejszej ekspozycji stałej poświęconej życiu i kulturze ludowej (Rytm życia i przedmiotów ludzkich) powstała pod koniec lat $60 . \mathrm{XX}$ wieku ${ }^{34}$, a fragmentaryczne zmiany wprowadzono na początku lat 2000, a następnie w 2015 i $2019 \mathrm{roku}^{35}$. Ostatnie zmiany wiążą się z zatrudnieniem nowego dyrektora w 2008 roku, od tego czasu muzeum podlega ciągłej, choć zmiennej, jeśli chodzi o natężenie w czasie, transformacji ${ }^{36}$.

Mimo licznych, wprowadzanych w duchu "progresywnej” etnografii, zmian w treściach pokazywanych na wystawie stałej, Żydzi - zwłaszcza jako aktywne podmioty - są nadal słabo widoczni w wizji narodu, którą można z niej wyczytać37. Wśród ponad czterdziestu sekcji tematycznych dotyczących polskiego folkloru Żydzi pojawiają się wyraźnie tylko w sześciu z nich, widoczni na archiwalnych zdjęciach dotyczących różnych aspektów życia wsi, a fotografie wprowadzono na wystawę na przełomie lat 80. i 9o. XX wieku³.

Zob. M. Dolińska Muzeum Etnograficzne w Krakowie - wierność tradycji, "Lud” 2003 nr 87, s. 83-109.

Zob. Sto i pół. Opowieściz Muzeum Etnograficznego w Krakowie, red. M. Szczurek, Muzeum Etnograficzne im. Seweryna Udzieli w Krakowie, Kraków 2011.

Zob. A. Bartosz Słowo wstępne, w: Rocznik Muzeum Etnograficznego im. Seweryna Udzieli w Krakowie, t. 16, Wspólnota poszukujących, red. M. Szczurek, Muzeum Etnograficzne im. Seweryna Udzieli w Krakowie, Kraków 2010, s. 5-6; tegoż Ethnographic Museums: The Invaluable Mirrors, w: Polish Museums, red. D. Folga-Januszewska, Bosz, Olszanica 2012, s. 134-155; tegoż Szumi coś i gwarzy, w: Lokalne Muzeum w globalnym świecie: Poradnik praktyczny, red. J. Hajduk, Ł. Piekarska-Duraj, P. Idziak, S. Wacięga, Małopolski Instytut Kultury, Kraków 2013, s. 146-150.

37 Por. E. Lehrer Jewish Poland Revisited: Heritage Tourism in Unquiet Places, Indiana University Press, Bloomington 2013; tejże "Most Disturbing Souvenirs": Curative Museology in a Cultural ConflictZone, w: Curatorial Dreams: Critics Imagine Exhibitions, ed. S. R. Butler, E. Lehrer, McGill-Queen's University Press, Montreal 2016, s. 46-63.

38 W 1985 roku podjęto decyzję o „modernizacji” wystawy i usunięciu z niej treści o wyraźnie komunistycznym wydźwięku. Zob. M. Dolińska Muzeum Etnograficzne. Sto i pół: opowieści z Muzeum Etnograficznego w Krakowie, red. M. Szczurek, Muzeum Etnograficzne im. Seweryna Udzieli w Krakowie, Kraków 2011. 
Brak ten szczególnie widać w wypadku części wystawy dotyczących prowadzenia karczmy, przedstawiających muzykę ludową ${ }^{39} \mathrm{i}$ ludowe wycinanki, czyli dziedzin, w których Żydzi odgrywali istotną rolę i z którymi nadal są kojarzeni w popularnej pamięci kulturowej. W zestawieniach zdjęć i artefaktów ilustrujących wiejskie życie społeczne i gospodarcze, w dużej gablocie prezentującej polskie stroje regionalne, a przede wszystkim w obszernych galeriach na drugim piętrze, poświęconych życiu codziennemu i rytuałom związanym z porami roku, kultura polska ukazywana przez muzeum jest przede wszystkim słowiańska i katolicka. Żydzi są najwyraźniej widoczni na wystawie przez pryzmat spojrzenia swoich etnicznie polskich sąsiadów - za sprawą masek i kostiumów kolędniczych oraz karnawałowych, a także jako kukiełki w szopkach lub figurki sprzedawane na jarmarku wielkanocnym.

Przed 2011 rokiem strategia kuratorska muzeum opierała się na tradycyjnie "naukowych” zasadach; komentarze kuratorskie zawierały krótkie, ogólne wprowadzenia do kolejnych części wystawy i zapewniały symboliczne interpretacje przedstawianych praktyk i wytworów kulturowych. Na przykład kostiumy Żydów zostały pokazane na wystawie głównie ze względu na magiczną, pośredniczącą funkcję, jaką pełnili oni w chłopskiej kosmologii, bez odniesienia do żydowskich doświadczeń czy konfliktów między grupami etnicznymi. Teksty, które towarzyszyły wystawie, przygotowano prawie wyłącznie w języku polskim, a ich ton i treść sugerowały, że są przeznaczone głównie dla publiczności przyjmującej katolicki i bezkrytyczny wobec prezentowanych materiałów punkt widzenia. Na przykład jeszcze pod koniec lat 9o. kukła w płaszczu i karykaturalnej masce ortodoksyjnego Żyda była jedynie opatrzona lapidarnym podpisem „Żyd”.

Od 2008 roku, kiedy stanowisko dyrektora Muzeum Etnograficznego w Krakowie objął Antoni Bartosz (oraz zatrudniono wielu nowych, młodych pracowników), w muzeum widać wyraźny postęp, jeśli chodzi o dyskursywne i estetyczne podejście do muzeologii etnograficznej, zarówno w zakresie strategii kuratorskich, jak i pod względem przyjaznego nastawienia wobec publiczności muzealnej. Świadczy o tym choćby otwarcie w muzeum sklepu z pamiątkami, zaangażowanie w projektowanie małej architektury (np. wyposażenia placów zabaw) z motywami etnograficznymi oraz organizacja wystaw plenerowych, a także proklamacja misji muzeum umieszczona na banerze na fasadzie jego siedziby głównej. Nowe hasło MEK - „Moje muzeum,

39 Zob. M. Waligórska Klezmer's Afterlife: An Ethnography of the Jewish Music Revival in Poland and Germany, Oxford University Press, New York 2013. 
muzeum o mnie" - zdawało się wyraźną odpowiedzią na coraz częstsze, zainicjowane na Zachodzie, apele o wzmocnienie społecznego znaczenia muzeów (relevance), uwzględnienie praktyk partycypacyjnych i demokratyzację dyskursu oraz narracji muzealnej (zwłaszcza w odpowiedzi na krytykę muzeów etnograficznych). Jest również reakcją na polską debatę dotyczącą wypierania się chłopskich korzeni przez polskie społeczeństwo po 1945 $\mathrm{roku}^{40}$. Na swojej stronie internetowej i w innych materiałach promocyjnych muzeum zaczęło prezentować się „postępowo”, inicjując i podkreślając wiele niekonwencjonalnych, eksperymentalnych inicjatyw, również takich, które miały na celu zainteresowanie mieszkańców Krakowa, zwłaszcza dzieci, zmarginalizowanym dziedzictwem miasta, obejmującym także dziedzictwo kultury żydowskiej"1.

Rozpoczęto również wprowadzanie znaczących zmian w wystawie głównej, takich jak pełna przebudowa galerii wiosennych tradycji i obrzędów ludowych pod szyldem projektu Od-nowa, stanowiąca radykalny odwrót od tradycyjnego, „naukowego” podejścia kuratorskiego. W tej nowej, przeformułowanej części wystawy nacisk położono na doświadczenie estetyczne, zastępując „nudne” prezentacje typowych obiektów w tradycyjnych gablotach muzealnych kolorową, całościową aranżacją „otoczenia”. Sala ta sprawia dziś wrażenie polskiej wsi wiosną dzięki jasnym, drewnianym ścianom i umieszczeniu na środku sali ogromnego pnia drzewa, wyrastającego do sufitu, który pomalowano w tęczowy motyw nawiązujący do polskiego rzemiosła ludowego, i otoczonego wygodnymi, zielonymi kanapami. Liczba pokazywanych muzealiów została radykalnie zmniejszona, a poszczególne obiekty podkreślono niekonwencjonalnymi witrynami o niestandardowych kształtach, które osadzono w ścianach - np. piorun sugerujący wiosenną burzę. Na ścianach umieszczono też kilka bliskich tej tematyce wielkoformatowych archiwalnych

Zob. A. Leder Prześniona rewolucja. Ćwiczenia z logiki historycznej, Wydawnictwo Krytyki Politycznej, Warszawa 2014.

Wystawy czasowe wychodziły poza i kwestionowały granice tego, co (w lokalnym kontekście) przyjęte i powszechnie akceptowalne, poruszając takie tematy jak islam i uchodźcy czy włączając parę gejów w ramy wystawy o współczesnych weselach. Przy ich przygotowywaniu stosowano także nowe metody: np. wystawę o ogródkach działkowych pochodzących z czasów socjalizmu poprzedziły długoterminowe badania terenowe z udziałem ich użytkowników; w przypadku innej wystawy wybór i opis obiektów został oparty na wspomnieniach grupy pracowników MEK. Por. M. Murzyn-Kupisz, J. Działek Muzea a budowanie kapitału społecznego w środowisku lokalnym, "Rocznik Muzeum Wsi Mazowieckiej w Sierpcu” 2014 nr 5, s. 19-40; K. Piszczkiewicz Ethnography in the Public Space, or How to Respond to Life, w: Extended Museum in its Milieu, ed. D. Folga-Januszewska, Universitas, Kraków 2018, s. 181-187. 
fotografii i cytatów zaczerpniętych z raportów etnograficznych oraz wiejskich pamiętników. Rząd delikatnych, ręcznie malowanych pisanek można oglądać z bliska, dostrzegać szczegóły zdobienia poszczególnych jajek, przesuwając staroświecką lupę osadzoną na metalowych prowadnicach. Dwie wpuszczone w ściany gabloty z drewnianymi figurkami z dorocznego krakowskiego odpustu wielkanocnego Emaus, w tym stale popularnymi figurkami Żydów, są przysłonięte ruchomymi panelami, dzięki czemu zwiedzający mogą odkrywać ukryte części wystawy. Tu także użyto szkieł powiększających i luster, których używanie sprzyja panującemu na wystawie nastrojowi zabawy.

Choć wspomnianą wyżej (r)ewolucję estetyczną można uznać za formę postępu w konstruowaniu narracji muzealnej, zrodziła ona także nowe problemy, szczególnie w odniesieniu do ujmowania tematów żydowskich. Można przypuszczać, że zmiany wprowadzone w galerii zwyczajów wiosennych sprawiają, że kwestia nawiązań do obyczajów żydowskich w tym kontekście pozostaje enigmatyczna i może nawet m niej c zy teln ie wyjaśniona niż wcześniej. Zredukowanie objaśnień tekstowych pozostawia prezentowane obiekty „na łasce” dowolnych, często nacechowanych uprzedzeniami, stereotypowych interpretacji, które przynoszą ze sobą zwiedzający. Ogranicza to możliwości zapoznania się z różnorodnymi podejściami i nowszymi spojrzeniami na pokazywane zjawiska. O ile zabawny pomysł wciągnięcia widza do aktywnego uczestnictwa przez udostępnienie lupy do „badania” eksponatów sprawdza się w wypadku pisanki, o tyle postać Żyda za szkłem powiększającym (il. 6) wywołuje egzotyzujące, a nawet rasistowskie skojarzenia.

Biorąc pod uwagę postępowe podejście do muzealnictwa deklarowane przez instytucję, która żywo reaguje na aktualne tematy, a także rosnące znaczenie i popularność kultury żydowskiej obserwowane w ostatnich latach w Polsce i w Krakowie, można byłoby oczekiwać, że krakowskie Muzeum Etnograficzne uwzględni w wystawie stałej sekcję poświęconą judaikom, nawet jeśli nie włącza kultury żydowskiej w bardziej zintegrowany sposób w swoją narrację „ludu polskiego", co stanowiłoby większe wyzwanie ${ }^{42}$. Byłoby to zgodne nie tylko z kierunkiem szerszej, postkolonialnej krytyki muzealnictwa etnograficznego, z którą MEK ogólnie zdaje się zgadzać - m.in.

Chociaż MEK nie pozyskiwało systematycznie judaików, posiada dziesięć takich obiektów (odzież oraz sztandary) oraz setki zdjęć i dokumentów archiwalnych, w tym pocztówek. Por. K. Wasilewska-Prędki Judaika w zbiorach Muzeum Etnograficznego im. Seweryna Udzieli w Krakowie-przegląd najważniejszych obiektów, "Krzysztofory” 2017 nr 35, s. 451-462, https://www. muzeumkrakowa.pl/images/upload/WYDAWNICTWA/Krzysztofory\%2035/KRZY.2017.24.Wasilewska-Predki.Kamila..pdf (20.09.2020). 
z postulatami dekonstrukcji hierarchii kulturowych i uwzględniania wielogłosowości narracji - ale także z lokalnymi uwarunkowaniami muzeum. Jest to instytucja położona w historycznej żydowskiej dzielnicy Krakowa, w budynku, który niegdyś służył jako szkoła żydowska. Na elewacji zewnętrznej mieści się tablica przedstawiająca przyjęcie Żydów do Polski przez Kazimierza Wielkiego, a rozwój muzeum związany jest z wybitnym powojennym dyrektorem - Tadeuszem Sewerynem - uznanym za „Sprawiedliwego wśród Narodów Świata” ${ }^{\prime 3}$. Warto zauważyć, że od początku kadencji Antoniego Bartosza tematy „żydowskie” - nawet te trudne emocjonalnie i politycznie - pojawiają się natomiast w muzeum prawie co roku w ramach wystaw c z a s o w y c h. Zostały one, z jednym niedawnym wyjątkiem, przygotowane w odpowiedzi na zewnętrzne impulsy, z udziałem partnerów z zewnątrz, przez artystów i kuratorów spoza samego muzeum, które zaoferowało przestrzeń wystawienniczą w swoim drugim budynku, oddalonym zaledwie o przecznicę od siedziby głównej ${ }^{44}$. Krakowskie Muzeum Etnograficzne zgodziło się również na różne krytyczne „interwencje” zwracające uwagę na sposoby pokazywania materiałów związanych z kulturą żydowską. Owe „interwencje” zostały zainicjowane przez osoby z zewnątrz ${ }^{45}$. Te ostatnie projekty i wydarzenia zarówno dowodzą wrażliwości personelu, zwłaszcza dyrektora, na kwestię uwzględniania i interpretacji kultury żydowskiej w muzeum, jak i wrażliwość tę zwiększają. Jednak własne działania kuratorów i kuratorek muzeum, zwłaszcza przy pracy z kolekcją i aranżacji wystawy głównej, często

43 Istnieją również dowody na to, że Żydzi mogli w czasach okupacji hitlerowskiej ukrywać się w drugim (oprócz gmachu głównego) budynku, który należy obecnie do muzeum (Dom Esterki).

44 Robert Gądek, osobisty kontakt z autorkami, 12.08.2019. Gądek jest zastępcą dyrektora Krakowskiego Festiwalu Kultury Żydowskiej. Wśród wystaw w MEK zainicjowanych i zorganizowanych przez Festiwal znajdują się: Niewinne oko nie istnieje Wojciecha Wilczyka (2009); Fotografie 1857-1900 (2010); Żydzi na winylach Rogera Bennetta, Davida Katznelsona i Josha Kuna (2011, jedyna z wymienionych, która została zaprezentowana w głównym budynku, w sali zajęć edukacyjnych); Macewy codziennego użytku Łukasza Baksika (2012); Pamiq̨tka, zabawka, talizman Eriki Lehrer (2013). W latach 2018-2019 MEK było oficjalnym partnerem projektu, w ramach którego Erica Lehrer, Roma Sendyka, Wojciech Wilczyk i kuratorka MEK Magdalena Zych przygotowali wystawę Widok zza bliska. Inne obrazy Zagłady. Był to jeden z rezultatów międzynarodowego projektu badawczego TRACES, finansowanego w ramach unijnego programu "Horyzont 2020" (zob. https://ec.europa.eu/programmes/horizon2020/en, 20.09.2020).

45 Zob. E. Lehrer Na szczęście to Żyd. Polskie figurki Żydów, Ha!art, Kraków 2014; Różnicowanie narodowego "my”: kuratorskie marzenia, red. E. Lehrer, R. Sendyka, Wydawnictwo Uniwersytetu Jagiellońskiego, Kraków 2019. 
wydają się ambiwalentne, pełne zahamowań. Od czasu do czasu czynią oni pewne kroki w kierunku bardziej krytycznego zaangażowania w tematykę żydowską, ale próby wprowadzenia na stałe zmian w ekspozycji okazują się ostrożne, przytłumione, nierzadko nietrwałe ${ }^{46}$.

Radykalną kuratorską zmianę, nawiązującą do krytycznych oczekiwań odbiorców z Zachodu, stanowiła stworzona przez interdyscyplinarny zespół pracowników MEK w 2011 roku wystawa czasowa zatytułowana Przejścia i powroty, przeznaczona do prezentacji za granicą ${ }^{47}$. Jej punktem wyjścia były osobiste wspomnienia członków zespołu i ich reakcje na przedmioty z kolekcji muzeum; następnie pracowano, by „wyszperać w zbiorach muzealnych źródła tematów na wskroś współczesnych, niepokojących, drażniących"48. Przemilczano jednak kwestię kontrowersyjnej natury muzealiów w różny sposób odnoszących się do kultury żydowskiej, które zajmowały na wystawie ważne miejsce. Innowacje estetyczne - zasłona z kluczy, przez którą musieli przejść goście, i przejście utworzone przez figuralne ule - budziły wrażliwość na magiczną kulturę ludową, również w odniesieniu do jej odmienności wobec kultury dominującej. Jednakże skojarzenie z magią "obcych" w ramach polskiego ludu pociąga za sobą nierozpoznane kwestie

Zaproponowany na Międzynarodowy Dzień Muzeów temat przewodni na 2017 rok brzmiał: "Muzea i kontestowane historie: wypowiedzieć niewypowiadalne w muzeach" ("Museums and Contested Histories: Saying the Unspeakable in Museums"). Podejmując go, młodzi kuratorzy MEK przygotowali na festiwal „Noc Muzeów” zestaw plakatów i pocztówek podkreślających "trudne tematy" w galeriach MEK. Jeden z plakatów, umieszczony w pobliżu masek kolędników, wkrótce zniknął, ale w końcu powrócił na dłużej. Zawierał pierwszą w historii muzeum wzmiankę o antysemityzmie jako istotnej ramie interpretacyjnej dla tych materiałów, choć nieco ukrytą w kilkuakapitowym tekście. Ostatnio MEK eksperymentował także z wieloetniczną integracją w ramach projektu Kto to wie(ś) - na własną rękę, na własną miarę, który odbywał się poza miastem, na terenie skansenu w Szymbarku. Wystawiono tam zdjęcia dawnych mieszkańców Małopolski, przedstawicieli różnych grup etnicznych i religijnych, przypominając "o bliskim i współzależnym bytowaniu, na którym opierało się wiejskie poczucie wspólnoty niewolne od kryzysów i napięć" (Muzeum Dwory Karwacjanów i Gładyszów w Gorlicach, Kto to wie(ś) - na własną rękę, na własną miarę, 2019, www.muzeum.gorlice.pl/wydarzenia-kulturalne/art/qkto-to-wie-na-wasn-rk-na-wasn-miarq, 29.07.2019).

47 Jak wyraża to katalog, „zaczęło się od pomysłu stworzenia wystawy zagranicznej, która będzie świeżą, niebanalną prezentacją kolekcji MEK" (M. Szczurek Przejścia i powroty, w: Przejścia i powroty: Ze zbiorów Muzeum Etnograficznego w Krakowie, red. M. Szczurek, Muzeum Etnograficzne w Krakowie, Kraków 2013, s. 9). Otwarto ją w Marsylii w 2011 roku oraz w berlińskim Staatliche Museen (Muzeum Kultur Europejskich) w 2013 roku. 
uprzedzeń i przemocy ${ }^{49}$. Na plakacie promocyjnym znalazł się na przykład jeden z dwóch umieszczonych na wystawie figuralnych uli przedstawiających ortodoksyjnych Żydów. Jednak w treści katalogu nie ma nawet wzmianki o różnorodnych, toczących się w tym czasie w Polsce debatach dotyczących przeszłości ani o trudnych emocjach polskich Żydów, które mógł wywołać sam ten przedmiot - drewniany Żyd wytworzony przez polskich chłopów, aby zapewnić sobie obfitość miodu ${ }^{50}$.

Równie dwuznaczne jest stopniowe znikanie ze stałej wystawy muzeum w ostatniej dekadzie elementów związanych z Żydami, szczególnie tych, które mogły być uznawane za bardziej kontrowersyjne. Najpierw zniknęła fotografia przedstawiająca kukłę ortodoksyjnego Żyda, zwisającą z drzewa. Wykonana we wsi Pruchnik w 1979 roku, dokumentowała coroczny rytuał bicia i palenia biblijnego Judasza przedstawionego jako przedwojenny polski Żyd. Ta tradycja, jak wspomniano wyżej, ostatnio odżyła, upolityczniona w związku z nastrojami antyimigranckimi i sprawą zwrotu mienia żydowskiego ${ }^{51}$. Przed transformacją galerii zwyczajów wiosennych w 2011 roku usunięto z niej ubrane w rytualne stroje manekiny reprezentujące grupy społeczne postrzegane jako „inne”, w tym wspomnianą wyżej figurę męską w stroju żydowskim i „cygańską" (romską) kobietę. Z galerii zwyczajów zimowych kolejno usunięto w 2017 roku grupę kolędników (wśród nich postać

49 Por. A. Cała The Image of the lew in Polish Folk Culture, The Hebrew University Magnes Press, Jerusalem 1995; J. Tokarska-Bakir Rzeczy mgliste.

50 Nie wspomina się również o tym, że klucze mogą kojarzyć się z wywłaszczeniami, przymusowymi migracjami, utratą domów i przywłaszczaniem sobie żydowskiej i niemieckiej własności przez Polaków (por. tytuł pionierskiej publikacji na temat wywłaszczenia Żydów: Klucze i kasa. O mieniu żydowskim w Polsce pod okupacją niemiecką i we wczesnych latach powojennych, 1939-1950, red. J. Grabowski, D. Libionka, Stowarzyszenie Centrum Badań nad Zagładą Żydów, Warszawa 2014).

51 Punktem kulminacyjnym antyimigranckiego i antymuzułmańskiego wiecu we Wrocławiu w listopadzie 2015 roku było spalenie kukły chasydzkiego Żyda - właściwie identycznej jak wspomniany wyżej "Judasz" - trzymającego flagę UE, podczas gdy tłum skandował "Bóg, honor i ojczyzna". Zob. Polish Anti-Refugee Protesters Burn Effigy of Orthodox /ew, "The Times of Israel”, 19.11.2015, www.timesofisrael.com/polish-anti-refugee-protesters-burn-effigy-of-orthodoxjew/ (20.09.2020). W Wielki Piątek 2019 roku mieszkańcy Pruchnika wskrzesili tradycję „wieszania Judasza", a członkowie tłumu (w tym wiele dzieci) domagali się dla słomianego żydowskiego wizerunku dodatkowych pięciu batów w ramach „zadośćuczynienia” (odnosząc się do współczesnych debat na temat zadośćuczynienia Żydom za wywłaszczone mienie sprzed II wojny światowej). Por. M. Mikrut-Majeranek Kontrowersyjne „wieszanie Judasza” w Pruchniku, "Histmag.org", 23.04.2019, https://histmag.org/Kontrowersyjne-wieszanie-Judasza-w-Pruchniku-18609 (20.09.2020). 
w długim płaszczu i masce przedstawiającej stereotypowe cechy żydowskie) oraz zestawy figur z szopek, które zazwyczaj zawierały co najmniej jedną żydowską postać. Niektóre z towarzyszących im zdjęć dokumentalnych, w tym jedno ukazujące polskich chłopów śmiejących się z mężczyzny przebranego za Żyda, jeżdżącego na turoniu (kukle przypominającej barana), również nie są już wystawiane $e^{52}$.

Ambiwalencję związaną z tematami żydowskimi należy rozpatrywać w odniesieniu do wielu powikłanych czynników: niepokojów, luk i przeszkód - niektóre z nich pojawiają się w rozmowach z pracownikami muzeum, inne rozpoznałyśmy intuicyjnie. Należą do nich następujące okoliczności i potencjalnie istotne uwarunkowania: 1. przedstawienie tematyki żydowskiej leży w gestii innych lokalnych muzeów (Muzeum Krakowa - oddziały Stara Synagoga i Fabryka Schindlera; Muzeum Narodowe; Żydowskie Muzeum Galicja); 2.w kolekcji MEK znajduje się bardzo skromna liczba odpowiednich obiektów; 3. kuratorzy MEK czują się niekompetentni w tej konkretnej dziedzinie $^{53}$; 4. pasywny lub aktywny brak zainteresowania żydowskimi tematami ze strony niektórych pracowników muzeum; 5. poczucie, że podkreślanie i/lub włączanie tematyki żydowskiej do wystaw nie byłoby mile widziane przez odbiorców; 6. brak zainteresowania lokalnej społeczności żydowskiej muzeum etnograficznym, a tym samym brak woli politycznej, by naciskać na włączenie kultury żydowskiej w całościową narrację muzealną; oraz 7 . napięcia polityczne związane z tematyką żydowską, które wzrosły od jesieni 2015 roku wraz z przejęciem władzy przez konserwatywną, prawicową partię. Chociaż Antoni Bartosz publicznie stwierdził, że należy do grona polskich „filosemitów"54, nie można w pełni ustalić głębokich motywacji, obaw i strategii kierownictwa muzeum. Oczywiste jest, że nawet jeśli muzeum zajęło się tematyką żydowską, zmieniający się kontekst kulturowy i polityczny, w którym

Warto również wspomnieć o klarownym, choć zwięzłym, opisie (niepochlebnych) wizerunków i wyobrażeń dotyczących Żydów w opracowaniu na temat polskich rytuałów chrześcijańskich zamieszczonym w wydanym w 1995 roku roczniku naukowym Muzeum Etnograficznego w Krakowie. Nie ma jednak o tych kwestiach żadnej wzmianki w wydanym piętnaście lat później rocznicowym tomie Sto i pół: Opowieści z Muzeum Etnograficznego w Krakowie, przeznaczonym dla szerszej publiczności. która ukończyła judaistykę na Uniwersytecie Jagiellońskim. seum Is a Story: A Conversation with the Museum Director, zob. www.festivalt.com/event/everymuseum-is-a-story-a-conversation-w-the-museum-director/ (20.09.2020). 
działa, sprawia, że dalsze angażowanie się w tę kwestię staje się coraz bardziej ryzykowne i tworzy rozmaite wyzwania, również w zakresie finansowania takich przedsięwzięć, co akcentują pracownicy omawianego muzeum ${ }^{55}$.

Zniknięcie pewnych obiektów związanych z Żydami ze stałych galerii krakowskiego Muzeum Etnograficznego można postrzegać negatywnie. Z tego punktu widzenia materiał, który został uznany za kontrowersyjny z perspektywy bardziej wymagających, nowych odbiorców i krytyków oraz zmiany podejścia do kształtowania wystaw muzealnych, zamiata się pod dywan - zamiast otwarcie się z nim skonfrontować, stosując krytyczne podejście kuratorskie. Jednak częściowe i czasem niepewne wysiłki muzeum, zmierzające do uwzględnienia i docenienia tematyki żydowskiej, z pewnością wskazują na to, jak delikatną kwestią jest negocjowanie osobistych, metodologicznych i politycznych przekonań oraz poczucia odpowiedzialności i obowiązku pomiędzy pracownikami muzeum oraz pomiędzy muzeum a instytucjami odpowiedzialnymi za ich nadzór i finansowanie. Zapraszanie zewnętrznych partnerów, aby „na obrzeżach” działania instytucji inicjowali okresowe, przekraczające zwyczajowe granice projekty może być nie tyle odsuwaniem odpowiedzialności, ile raczej sprytnym nawigowaniem na zdradliwych wodach polityki historycznej i kulturalnej.

\section{Zakończenie}

Muzea oraz ich przedstawiciele są jednocześnie ważnymi ośrodkami aktywizmu i konserwatyzmu. Dzięki nim otaczające nas dyskursy kulturowe, polityczne i dyscyplinarne - jak też opór wobec nich - znajdują wyraz w praktykach kuratorskich. Na przykładzie muzeów etnograficznych można w szczególności obserwować zarówno potencjał tych "gęstych" pod względem symbolicznym i materialnym instytucji - gdy starają się one przejść od przedstawienia bardziej wykluczającego, monoetnicznego modelu narodu (polskiego) do modelu uwzględniającego przeszłą i współczesną różnorodność etniczną i kulturową - jak i ograniczenia, które napotykają. Naszym

55 Postawy wyrażane przez władze szczebla centralnego - coraz bardziej konserwatywne i ukierunkowane nacjonalistycznie - znacząco wpływają na możliwości działania i zasoby muzeum. W ostatnim czasie MEK zmagał się m.in. z opóźnieniami remontu pozyskanych przez muzeum nowych budynków przy realizacji dużego projektu, współfinansowanego przez UE (zob. M. Kursa /akWam się kojarzy Kobierzyn?Wkrótce zmieniciezdanie, „Wyborcza.pl”,13.05.2017, https://Kraków. wyborcza.pl/Kraków/7,44425,21803348,jak-wam-sie-kojarzy-kobierzyn-wkrotcezmienicie-zdanie.html, 20.09.2020). 
głównym celem było zrozumienie wyzwań stojących na drodze do stopniowych zmian.

Dwa analizowane muzea zmagają się z brakiem solidnego modelu międzyetnicznej integracji w tradycji muzealnej folklorystyki (Volkskunde), która w całej Europie była niemal wyłącznie etnonacjonalistyczna w swoim podejściu do klasyfikacji etnograficznych. W Polsce, zwłaszcza na terenie Galicji, polskie elity wykorzystywały rozwijające się nauki o kulturze, aby skupić się na regionalnej, wiejskiej tradycji chłopskiej, którą próbowały zmobilizować i zintegrować $w$ ramach głównego nurtu kultury polskiej i „ducha narodowego" uzasadniając w ten sposób polskość poszczególnych terenów ${ }^{56}$. Związki Żydów z rzemiosłem, handlem i środowiskiem miejskim (zarówno wielkomiejskim, jak i małomiasteczkowym) powodowały, że w przeciwieństwie do społeczności chłopskich diaspora żydowska była raczej transregionalna niż regionalna. Stąd trudno jej kulturę wpisać w powszechną, regionalnie zorientowaną logikę kuratorską, którą można na przykład obserwować w korytarzu krakowskiego Muzeum Etnograficznego, dotyczącym „regionalnego stroju chłopskiego". Żydzi są więc nieobecni w tej części ekspozycji mimo ikonicznego statusu żydowskiego stroju rytualnego w Polsce. Jednocześnie Żydzi nie pasują zbyt dobrze do równoległej tradycji Völkerkunde, etnografii „innych”, ,egzotycznych" ludów (exotic other), spotykanych na zagranicznych wyprawach. Choć zawsze wyróżniali się odmiennością [od wyobrażonych "nas" - przyp. red.], byli jednocześnie lokalni i swojscy.

Dzisiejsze wysiłki na rzecz wypracowania nowego języka przedstawiania kultury żydowskiej w muzeach etnograficznych wymagają nowego przedefiniowania Żydów jako podmiotu badań etnograficznych i praktyk kuratorskich. Odbywa się to rzecz jasna równolegle do ponowoczesnej, postsocjalistycznej reinterpretacji „kultury polskiej” dokonującej się w czasie, gdy antropologowie i krytycy kultury odrzucili samą ideę jednolitych, homogenicznych „kultur”, uznając ją za przestarzałą i opresyjną. Kuratorskie próby przedstawiania polskich Żydów w muzeach etnograficznych po Zagładzie rodzą wiele dodatkowych problemów praktycznych, politycznych i emocjonalnych. Różne próby inkluzywnego traktowania Żydów w takich muzeach (a także często brak takich wysiłków) odzwierciedlają nacechowany niepewnością i napięciami status tej społeczności w dominujących wizjach narodu polskiego, w których była ona niekiedy nie tylko wykluczana, lecz także zwalczana i atakowana.

56 Por. K. Stauter-Halstead The Peasant. 
Analogiczne muzea w Europie Zachodniej i Ameryce Północnej w szerokim zakresie, choć w różnym stopniu, odpowiadają na żądania pluralizacji, które towarzyszą zmianom demograficznym i związanym z nimi oczekiwaniom politycznym ze strony mniejszości oraz wspierających je osób i instytucji. Z perspektywy w dużej mierze monoetnicznego państwa polskiego dyskurs wielokulturowości jest jednak nadal nowy i ma chwiejne podstawy, ponieważ jest zakorzeniony w nierównomiernie rozwijającej się społecznej wyobraźni. Wyobraźnia ta na zmianę odwołuje się do historii wielokulturowości, zamiaru europeizacji tożsamości oraz potrzeby zmierzenia się $\mathrm{z}$ traumatyczną historią wojenną lub też pozostaje pod wpływem silnych tendencji konserwatywnych i regresywnych, które przesłaniają te dążenia lub przeciwstawiają się im.

Nowe dyskursy podejmowane przez postępowych dyrektorów naprawdę trudno krytycznie wykorzystywać w społeczeństwie, w którym konstytuowanie się zbiorowego "ja” jest przedmiotem gorących sporów. Kwestia podejścia muzeów do pokazywania kultury mniejszości etnicznych dotyczy nie tylko Żydów, ale też pozostałych „innych”, którzy mieszkali na historycznych ziemiach polskich (np. Romowie, Ukraińcy, Białorusini, Niemcy) ${ }^{57}$. Ze względu na rosnącą liczbę ukraińskich imigrantów w Polsce spodziewamy się, na przykład, że na pierwszy plan wysuną się w najbliższym czasie problemy związane z przedstawianiem historii i kultury ukraińskiej w polskich muzeach. W tej samej chwili, gdy ICOM debatuje nad radykalnie postępową nową definicją terminu i funkcji "muzeum”, polskie władze mają tendencję do promowania tradycyjnych w formie sposobów „celebrowania” dziedzictwa, o uroczystym i patriotycznym charakterze, wyrażając niechęć do wszystkiego, co wykracza poza nie. W takim klimacie popierający pluralizm kulturowy dyrektorzy i kuratorzy muzealni stają przed zadaniem nie do pozazdroszczenia.

Krytyczka sztuki i kuratorka Magdalena Ujma pochwaliła śmiałe zmiany krakowskiego Muzeum Etnograficznego wdrożone po 2008 roku. Zwróciła jednak uwagę na ograniczenia przyjmowanego przez Antoniego Bartosza „ogólnohumanistycznego podejścia”, które pobrzmiewa echem dyskursu „ciekawości i szacunku", proponowanego na przełomie wieków przez założyciela

57 MEK nie zorganizowało nigdy wystawy poświęconej Romom, którzy mieszkali w Krakowie od XV wieku, choć posiada w swojej kolekcji ponad 70 fotografii, pocztówek i rycin dokumentujących ich codzienne życie w tym mieście. Por. A. Kapusta, P. Kapusta Obiekty romskie w archiwum Muzeum Etnograficznego im. Seweryna Udzieli w Krakowie. Rekonesans antropologiczny, "Studia Romologica" 2018 nr 11, s. 299-336. 
muzeum, Seweryna Udzielę. Sięgając wstecz i w głąb, zamiast do przodu i na zewnątrz, do nowszych i bardziej różnorodnych źródeł teorii i krytyki muzeów, Muzeum Etnograficzne w Krakowie rezygnuje jej zdaniem z możliwości (a być może uchyla się od odpowiedzialności) „wyostrzenia spojrzenia na siebie" i lepszego wykorzystania potencjału zmiany, który mógłby zostać uwolniony przez taką samokrytykę $e^{58}$. Ujma nazywa jednocześnie podejście muzeum „terapeutycznym”, w przeciwieństwie do „krytycznego”, ponieważ zachęca ono raczej do refleksji indywidualnej (dotyczącej „ja”) niż społecznej, która wymagałaby prawdziwego spotkania z „innym”.

Katalizatorem takiej refleksji mogą stać się nowe inicjatywy społeczne. We wrześniu 2019 roku z wystawy w krakowskim Muzeum Etnograficznym zdjęto maski kolędników, w tym najbardziej karykaturalne przedstawienia Żydów (il. 5). Na decyzję o ich usunięciu wpłynęła otwarta dyskusja z dyrektorem muzeum, zainicjowana tego lata przez lokalną organizację FestivALT - „Nowe nurty współczesnej sztuki żydowskiej” w ramach cyklu wydarzeń w Krakowie zatytułowanego „Re-Jewing Polish Folk Culture”59. Wydaje się jasne, że to w reakcji na ból i gniew wyrażony przez większość uczestników tego wydarzenia, będących pochodzenia żydowskiego, Adam Bartosz uznał maski za zbyt kontrowersyjne i krzywdzące, aby można je było wystawiać.

Takie działania podejmowane przez muzeum $\mathrm{w}$ reakcji na sygnały z otoczenia obrazują, w jakim stopniu w praktyce jest ono przygotowane, aby trwać przy swojej nowej strategii, kładącej nacisk na wielogłosowość, dialog, autokrytycyzm i szacunek dla innych ${ }^{60}$, szczególnie w odniesieniu do grup społecznych, których bezpośrednio dotyczą wystawiane materiały. Chociaż podejmujące trudne tematy wystawy czasowe mogą mieć duże znaczenie, są efemeryczne. Natomiast zastosowanie krytycznego podejścia kuratorskiego w odniesieniu do wystawy stałej sprawia, że przypisywane prezentowanym obiektom znaczenia w większym stopniu do nich „przywierają". Zakłóca to tradycyjny muzealny porządek i wprowadza, zarówno w przestrzeń wystawienniczą muzeów, jak i w ich „zakulisową" działalność, nowe, inspirujące wątki, które mogą w nieszablonowy, nieoczywisty sposób pobudzić pracowników muzeów, ich odbiorców oraz inne osoby i instytucje w ich otoczeniu.

58 M. Ujma Muzeum Etnograficzne: świeże spojrzenie, "Obieg”, 29.03.2012, https://archiwum-obieg.u-jazdowski.pl/teksty/24505 (20.09.2020). with the Museum Director.

60 A. Bartosz Ethnographic Museums: The Invaluable Mirrors. 
Niezależnie od tego, czy polskie muzea etnograficzne uwzględniają wymagania krytycznej, postkolonialnej muzealnej awangardy, zmiana ich podejścia do konstruowania narracji muzealnej konieczna jest już od dłuższego czasu. Zmiana ta polegałaby na odejściu od tego, co Barbara Kirshenblatt-Gimblett nazywa kuratorstwem in situ, gdzie muzealia są prezentowane jako części domniemanych, często utopijnych całości kulturowych, do kuratorstwa w kontekście (in context), które dzięki uwzględnieniu tła historycznego i okoliczności kolekcjonowania, dzięki formułowaniu pytań i inspirowaniu porównań działa pedagogicznie, tworząc ramy dla własnej aktywności zwiedzającego, a zarazem „ratuje [muzealia] od błahości”61. Taka zmiana wymagałaby raczej p o d k r e śl e $n$ i a, iź żydowska kultura materialna często była i jest przedmiotem kontestacji, a nie zacierania, ignorowania czy przemilczania prawdy, że do niej dochodziło. Uniemożliwiłoby to pominięcie jej historycznej i politycznej specyfiki oraz przemocy symbolicznej, jaka ją nierzadko otacza.

Biorąc pod uwagę utrzymujący się w Polsce głęboko ambiwalentny stosunek do żydowskiego dziedzictwa i historii, opisywane przez nas kuratorskie wyzwania dotyczące prezentowania tematyki żydowskiej w muzeach etnograficznych świadczą także o pewnym zrozumiałym braku poczucia pewności kierownictwa i pracowników muzeów w zakresie poruszania się w tej problematyce, zwłaszcza w kontekście istotnych bieżących zmian społecznych i politycznych. We współczesnych realiach, w których władze siłowo wprowadzają politykę historyczną opartą na gloryfikacji pewnych kwestii i wykorzystują politykę kadrową, by ingerować w praktyki kuratorskie muzeów, których narracje uważają za niewystarczająco wspierające polską dumę narodową ${ }^{62}$, a jednocześnie dla własnych, cynicznych celów wykorzystują pewne uproszczone odwołania do dziedzictwa żydowskiego - zarówno obecność, jak i nieobecność Żydów na wystawach muzealnych są istotnymi, budzącymi kontrowersje i prowokującymi do przemyśleń tematami.

61 B. Kirshenblatt-Gimblett Objects of Ethnography, w: Exhibiting Cultures: The Poetics and Politics of Museum Display, ed. I. Karp and S.D. Lavine, Smithsonian Institution Press, Washington DC 1991, s. 386-443.

62 Na temat takich ingerencji zob. M. Gessen Poland's Ruling Party Puts an Extraordinary Museum of Polish-Jewish History into Limbo, "New Yorker", 23.09.2019, https://www.newyorker.com/ news/our-columnists/ polands-ruling-party-puts-an-extraordinary-museum-of-polish-jewishhistory-into-limbo (20.09.2020); P. Machcewicz Muzeum, Znak Horyzont, Kraków 2017; A. Polska A Cultural Emergency in Warsaw: ArtistAgnieszka Polska Speaks Out ,"Frieze”, 22.11.2019, https://frieze.com/article/cultural-emergency-warsaw-artist-agnieszka-polska-speaks-out (20.09.2020). 


\section{Postscriptum}

Po tym, jak pierwsza wersja niniejszego artykułu trafiła do druku, Erica Lehrer, przystępując do kolejnej z serii krytycznych interwencji w Muzeum Etnograficznym w Krakowie, podjętej we współpracy z kuratorką tego muzeum, Magdaleną Zych, otrzymała w listopadzie 2019 zdjęcia zupełnie nowej aranżacji pustej przestrzeni po karykaturalnych maskach żydowskich (il. 5). Znalazł się na nich nowy, osobisty w formie tekst, napisany i podpisany przez Zych, stanowiący uzupełnienie głównego tekstu wprowadzającego do galerii (umieszczonego na standardowej czarnej planszy wielkości plakatu). Tekst Zych, wydrukowany na arkuszu laminowanego żółtego papieru przymocowanym do ściany za pomocą okrągłych metalowych uchwytów, napisany jest nowym językiem. Kwestionuje „niewinność” masek i tradycję, z której się one wywodzą, a także mówi o wspieranym przez nie po dziś dzień historycznym antysemityzmie. Na nowej wystawie zastąpiono również same maski - eksponaty sprawiające ból wielu zwiedzającym - większą liczbą archiwalnych, niewielkich zdjęć podobnych masek, pochodzących z lat 19381987. Nowy tekst autorefleksyjnie stawia pytanie o to, czy muzeum troszczyło się o uczucia Żydów i Romów, którzy hasło krakowskiego Muzeum Etnograficznego „moje muzeum” odbierali jako ironiczne. Świadczy to o konieczności i potencjale dialogu między muzeum a społecznością; postępujące z czasem zmiany wynikają ze wsłuchania się w głos drugiej strony.

Jednak w obecnym klimacie politycznym nie jest jasne, czy nowe eksperymentalne strategie muzeów - jakkolwiek niedoskonałe, lecz stanowiące ważne kroki milowe - będą kontynuowane. W czasie, gdy pisałyśmy ten artykuł, Adam Czyżewski zakończył pracę w warszawskim muzeum, a plany Antoniego Bartosza wobec krakowskiej placówki utknęły w martwym punkcie z powodu wstrzymania funduszy na ich realizację. Podobnie jak muzea historyczne, również muzea kultury stają się w Polsce polami bitewnymi, na których ścierają się rozbieżne wizje narodu, a także roli muzeów we współczesnym świecie.

Przełożyła Łucja Lange Przekład przejrzała i skorygowała Maria Kobielska

\section{Podziękowania}

Autorki dziękują Magdalenie Waligórskiej, Joannie Wawrzyniak i Sarze Zarrow za komentarze do wcześniejszej wersji tego artykułu. 


\section{Abstract}

\section{Erica Lehrer}

CONCORDIA UNIVERSITY (CANADA)

\section{Monika Murzyn-Kupisz}

JAGIELLONIAN UNIVERSITY (CARCOW)

Making Space for Jewish Culture in Polish Folk and Ethnographic Museums: Curating Social Diversity after Ethnic Cleansing

Looking beyond Poland's internationally lauded new Jewish museums, this article asks how Jews are represented in longer-standing folk and ethnographic museums whose mandates have been to represent the historical culture of the Polish nation. How have such museums navigated growing internal pressures to incorporate Jews and reconsider the boundaries of "Polishness" alongside external pressures to rethink the function and approach of ethnographic museology? Based on three museums that have taken three different approaches to Jewishness - what we call cabinet of Jewish curiosities, two solitudes, and ambivalent externalisation - we assess the roles played by inherited discourses and structures as well as human agents within and beyond the museum. We illuminate how social debate about the character of the nation (and Jews' place in it) plays out in museums at a moment in their transition from nineteenth- to twenty-first-century paradigms and how a distinctively Polish path toward a"new museology" is emerging in conversation with and resistance to its Western counterparts.

\section{Keywords}

critical curating, ethnographic exhibitions, heritage, Jews, multiculturalism, Poland 